\title{
IMPACTO DO LODO DE CURTUME NOS ATRIBUTOS BIOLÓGICOS E QUÍMICOS DO SOLO
}

\author{
AleXANDRe MARTin MARTines
}

Dissertação apresentada à Escola Superior de Agricultura "Luiz de Queiroz", Universidade de São Paulo, para obtenção do título de Mestre em Agronomia, Área de Concentração: Solos e Nutrição de Plantas.

P I R A C I C A B A

Estado de São Paulo - Brasil

Junho -2005 


\title{
IMPACTO DO LODO DE CURTUME NOS ATRIBUTOS BIOLÓGICOS E QUÍMICOS DO SOLO
}

\author{
AleXANDRe MARTin MARTines \\ Engenheiro Agrônomo
}

Orientadora: Profa. Dra. ELKE JURANDY BRAN NOGUEIRA CARDOSO

Dissertação apresentada à Escola Superior de Agricultura "Luiz de Queiroz", Universidade de São Paulo, para obtenção do título de Mestre em Agronomia, Área de Concentração: Solos e Nutrição de Plantas.

P I R A C I C A B A

Estado de São Paulo - Brasil

Junho -2005 
Dados Internacionais de Catalogação na Publicação (CIP) DIVISÃO DE BIBLIOTECA E DOCUMENTAÇÃO - ESALQ/USP

Martines, Alexandre Martin

Impacto do lodo de curtume nos atributos biológicos e químicos do solo / Alexandre Martin Martines. - - Piracicaba, 2005.

$62 \mathrm{p}$.

Dissertação (mestrado) - - Escola Superior de Agricultura Luiz de Queiroz, 2005.

Bibliografia.

1. Lodo de curtume 2. Microbiologia do solo 3. Química do solo I. Título

CDD 631.41

"Permitida a cópia total ou parcial deste documento, desde que citada a fonte - $\mathrm{O}$ autor" 
"Quem tem ideal tem futuro, mas

aquele que apenas vive o presente

nada sabe do que há de ser o

amanhã”

A Deus,

por iluminar meus caminhos

Aos meus pais Abrão e Diva e ao meu irmão Samuel por me mostrarem, desde muito cedo, o verdadeiro significado da palavra família. 


\section{AGRADECIMENTOS}

À Universidade de São Paulo, Escola Superior de Agricultura "Luiz de Queiroz”, em especial à Coordenação do Programa de Pós-Graduação em Solos e Nutrição de Plantas pelo voto de confiança.

Ao CNPq, pelo apoio financeiro concedido durante a realização do programa. Ao curtume Vanzella pelo apoio financeiro e fornecimento dos resíduos.

À Professora Dra. Elke Jurandy Bran Nogueira Cardoso, pela atenção, amizade, orientação, incentivo e convivência.

Ao professor Dr. Antonio Enedi Boaretto, pela atenção, amizade e valiosas sugestões.

Aos professores Dr. Carlos Tadeu dos Santos Dias e Dra Maria Emília Matiazzo-Prezotto pelos ensinamentos e sugestões.

Aos Técnicos do Laboratório de Microbiologia do Solo do Departamento de Solos e Nutrição de Plantas - ESALQ/USP Denise de Lourdes Colombo Mescolotti e Luis Fernando Baldesin, pela amizade e apoio na condução dos experimentos, indispensáveis para a realização desse trabalho.

A todos os colegas do Curso de Pós-Graduação em Solos e Nutrição de Plantas - ESALQ/USP, em especial a Adriel Ferreira da Fonseca e Cristiano Alberto de Andrade pela amizade, sugestões e auxílio na realização de diversas análises.

Aos companheiros de laboratório, José Pereira da Silva Júnior, Paulo Mendes Filho, Fernanda Carvalho, Dilmar Baretta, Rafaela de Fátima Neroni e Maria Elda Ferreira César pela convivência e grandiosas discussões intelectuais e profissionais.

Aos meus familiares, em especial à tia Cleide pela atenção e consideração. Aos amigos de ontem e de hoje, Luis Fabiano Verri, Cassiano Garcia, Daniel 
Portolese, Luis Gustavo Gonçalves, Paulo e Ana Lucia Dorta, Cristiano Elemar Voll, Ricardo Augusto Gorne Viani, Lucas Carvalho Basílio de Azevedo, José Lavres Junior, Anderson Lange, Mauro Guida dos Santos, Cleusa Pereira Cabral, Lucia Pittol Firme, Virginia Damin, Jeanidy Pazinato, Valesca Pandolfi, Priscylla Ferraz e Rodrigo Otávio Câmara Monteiro, com os quais vivi momentos marcantes que nunca serão esquecidos. 


\section{SUMÁRIO}

\begin{tabular}{|c|c|}
\hline \multicolumn{2}{|l|}{$\begin{array}{lll}20 & \text { Página }\end{array}$} \\
\hline RESUMO. & .. viii \\
\hline SUMMARY &.$\quad \mathrm{x}$ \\
\hline 1 INTRODUÇÃO... & 1 \\
\hline 2 REVISÃO DE LITERATURA........ & 3 \\
\hline 2.1 Processo industrial de curtimento de peles............ & 3 \\
\hline 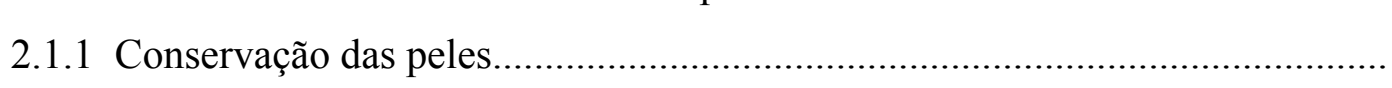 & 3 \\
\hline 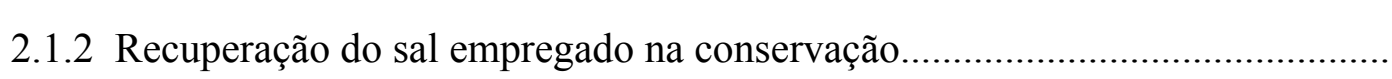 & 4 \\
\hline 2.1.3 Operação de ribeira. & 4 \\
\hline
\end{tabular}

2.2 Resíduos gerados durante o processamento das peles.......................................... 7

2.3 Uso do lodo de curtume na agricultura............................................................ 10

2.3.1 Mineralização do nitrogênio.............................................................................. 10

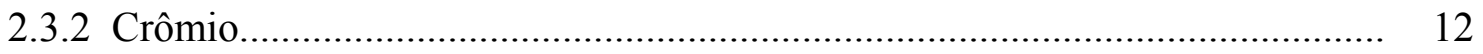

2.3.3 Salinização, sodicidade e condutividade elétrica............................................. 14

2.3.4 Efeito na microbiota........................................................................... 16

3 MATERIAL E MÉTODOS...................................................................... 19

3.1 Caracterização dos solos............................................................................. 19

3.2 Caracterização do lodo de curtume................................................................... 20

3.3 Doses de lodo de curtume utilizadas nos experimentos...................................... 21

3.4 Estudo 1: Avaliação da degradação do lodo de curtume....................................... 23

3.4.1 Análise dos dados coletados........................................................................ 23 
3.5 Estudo 2: Alterações nos atributos biológicos e químicos dos solos e efeito sobre a cultura da soja após aplicação de doses crescentes de lodo de curtume.

3.5.1 Avaliação da massa de matéria seca da parte aérea e produtividade de grãos. 25

3.5.2 Avaliação da massa de matéria seca e número de nódulos................................ 25

3.5.3 Teor de sódio e crômio na parte aérea das plantas............................................ 26

3.5.4 Avaliações microbiológicas...................................................................... 26

3.5.4.1 Estimativa do número mais provável de bactérias totais nos solos............... 26

3.5.4.2 Estimativa do número mais provável de microrganismos amonificadores... 27

3.5.4.3 Carbono da biomassa microbiana............................................................. 27

3.5.5 Análise química dos solos.......................................................................... 28

3.5.6 Análise estatística..................................................................................... 29

4 RESULTADOS E DISCUSSÃO.............................................................. 30

4.1 Estudo 1: Avaliação da degradação do lodo de curtume..................................... 30

4.1.1 Carbono liberado na forma de $\mathrm{CO}_{2}$ e taxa de degradação.............................. 30

4.1.2 Cinética química da degradação do carbono orgânico.................................... 34

4.2 Estudo 2: Alterações nos atributos biológicos e químicos dos solos e efeito sobre a cultura da soja após aplicação de doses crescentes de lodo de curtume 36

4.2.1 Transformações do nitrogênio no solo............................................................ 36

4.2.2 Massa de matéria seca da parte aérea e produtividade de grãos....................... 42

4.2.3 Condutividade elétrica (CE), sódio trocável e pH dos solos............................ 46

4.3 Apreciação geral dos resultados obtidos.............................................................. 53

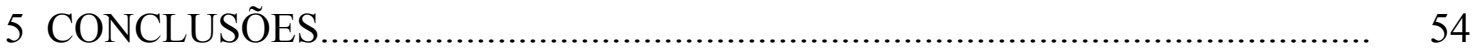

REFERÊNCIAS BIBLIOGRÁFICAS............................................................ 55 


\title{
IMPACTO DO LODO DE CURTUME NOS ATRIBUTOS BIOLÓGICOS E QUÍMICOS DO SOLO
}

\author{
Autor: ALEXANDRE MARTIN MARTINES \\ Orientadora: Profa. Dra. ELKE JURANDY BRAN NOGUEIRA CARDOSO
}

\section{RESUMO}

Devido ao seu elevado teor de nutrientes e potencial de neutralização da acidez do solo, a utilização de lodos de curtume em áreas agrícolas pode ser uma alternativa para disposição e reciclagem desses resíduos. Por outro lado, o acúmulo no solo de altas concentrações de alguns elementos, como o nitrogênio, sódio e o crômio, geralmente contidos nos lodos de curtume, podem proporcionar impactos negativos ao meio ambiente. Foram conduzidos experimentos utilizando-se três solos: Nitossolo Vermelho eutroférrico típico (NVef) com textura muito argilosa, Latossolo Vermelho Amarelo distrófico típico (LVAd) com textura argilosa e Neossolo Quartzarênico órtico típico (RQo) com textura arenosa. O lodo de curtume empregado nos experimentos foi composto de uma mistura na proporção de 1:1 de lodo do caleiro, mais o lodo primário da estação de tratamento de efluentes, resultante da precipitação dos efluentes gerados no processo, com exceção dos efluentes que contém crômio, sendo as doses aplicadas (base seca) no NVef e LVAd equivalentes a 0, 6, 12, 24, $36 \mathrm{Mg} \mathrm{ha}^{-1}$ e 0, 3, 6, 12, $24 \mathrm{Mg} \mathrm{ha}^{-1}$ para o RQo. Os experimentos conduzidos em laboratório tiveram por objetivo avaliar a cinética de degradação da fração orgânica do lodo após aplicação em doses crescentes nos solos. O delineamento experimental, para cada solo, foi inteiramente casualizado, em fatorial 5 x 21 ( 5 doses e 21 épocas de avaliação), com três repetições. Cada dose de 
lodo foi aplicada em $200 \mathrm{~g}$ de terra que foram colocados em frasco respirométrico de 1,5 L, hermeticamente fechado. A mineralização da fração orgânica do lodo foi determinada pela captura do $\mathrm{CO}_{2}$ liberado durante um período de 105 dias. Os dados de $\mathrm{CO}_{2}$ acumulado foram ajustados ao modelo de cinética química de primeira ordem e determinação da taxa de degradação. A taxa de degradação do carbono variou de 101,28 a 57,87\%. Taxas de degradação mais elevadas podem estar relacionadas com a estimulação de decomposição de material orgânico pré-existente, decorrente da aplicação de lodo de curtume, que estimula a atividade microbiana edáfica. Já as menores taxas de degradação, que ocorreram apenas nas doses mais altas, podem estar relacionadas com tal aumento do conteúdo orgânico adicionado, que tenha suplantado a capacidade de degradação dos microrganismos contidos nos solos. Os experimentos conduzidos em casa de vegetação tiveram por objetivo avaliar as alterações microbiológicas e químicas nos solos após a aplicação de doses crescentes de lodo de curtume e seu efeito sobre a cultura da soja. $\mathrm{O}$ delineamento experimental, para cada solo, foi inteiramente casualizado, em fatorial $5 \mathrm{x}$ 4 (5 doses e 4 épocas de avaliação) com quatro repetições. Cada parcela experimental foi constituída por um vaso plástico contendo duas plantas cultivadas em $4 \mathrm{~kg}$ de solo. A mineralização do nitrogênio orgânico foi mais intensa até 44 dias. As doses de 17, 23 e 6 $\mathrm{Mg} \mathrm{ha}{ }^{-1}$, respectivamente para o NVef, LVAd e RQo, proporcionaram ganhos de produtividade de grãos de 370, 247 e 72\% em relação às testemunhas (dose 0). As doses que prejudicaram o desenvolvimento das plantas foram acima desses valores, causando a morte de algumas plantas. 


\section{IMPACT OF TANNERY SLUDGE ON THE BIOLOGICAL AND CHEMICAL ATTRIBUTES OF SOIL}

Author: ALEXANDRE MARTIN MARTINES

Advisor: Prof. Dr. ELKE JURANDY BRAN NOGUEIRA CARDOSO

\section{SUMMARY}

Due to its high nutrient content and its neutralizing potential for the soil acidity, the utilization of tannery sludge in agricultural areas can be an alternative for its disposal and recycling. On the other hand, the soil accumulation of high concentrations of some elements such as nitrogen, sodium and chromium, commonly found in tannery sludge, can result in negative impacts on the environment. The experiments were carried out with three types of soils: a Kandiudalfic Eutrudox (NVef) with a very clayey texture, a Typic Hapludox (LVAd) with clayey texture and a Typic Quartzipsamment (RQo) with a sandy texture. The tannery sludge used in these experiments was composed of a mixture of liming sludge and the primary sludge from the wastewater treatment station, in the proportion 1:1, with the exception of the wastewater with chromium. The amount of sludge (dry basis) added to the NVef and the LVAd soils were equivalent to $0,6,12$, 24, $36 \mathrm{Mg} \mathrm{ha}^{-1}$ and $0,3,6,12,24 \mathrm{Mg} \mathrm{ha}^{-1}$ were added to the RQo soil. The objective of the laboratory experiment was to evaluate the decomposition kinetics of the organic fraction of the tannery sludge, after its addition to the soils in increasing doses. For each soil the experiment had a completely randomised factorial design 5 x 21 ( 5 doses and 21 evaluation times) with three replicates. Each sludge dose was mixed with $200 \mathrm{~g}$ of soil and incubated in $1.5 \mathrm{~L}$ tightly closed respirometric jars. The mineralization of the organic fraction was determined by the capture of the $\mathrm{CO}_{2}$ evolved during the 105 days 
incubation period. The accumulated $\mathrm{CO}_{2}$ data were adjusted to a first order chemical kinetics model and the carbon degradation rate was determined. The carbon degradation rate varied between 101.28 and $57.87 \%$. The highest degradation rates can be related to the stimulation of preexisting organic material, as the tannery sludge amendment stimulated the soil microbial activity. Conversely, the lowest degradation rates, which occurred only at the highest sludge doses, can be related to such a great increase in the organic content that it overwhelmed the decomposition capacity of the soil microorganisms. The experiments carried out in the glasshouse aimed at evaluating the microbiological and chemical changes in the soils after amendment with increasing amounts of tannery sludge and its effects on soybeans. The experimental design for each soil was a randomised factorial $5 \times 4$ (5 doses and 4 evaluation times) with four replicates. Each plot consisted of a plastic pot with two plants growing in $4 \mathrm{~kg}$ of soil. The mineralization of organic nitrogen was higher during the first 44 days of incubation. Respectively for NVef, LVAd and RQo, the doses of 17, 23 e $6 \mathrm{Mg} \mathrm{ha}^{-1}$ provided increases of 370,247 and $72 \%$ in grains productivity in relation to the control (dose 0 ). The doses that harmed plant development were above those values, causing the death of plants in some cases. 


\section{INTRODUÇÃO}

Em 2003, o Brasil passou a ter um dos maiores rebanhos comerciais de bovinos do mundo, com 195,5 milhões de animais (IBGE, 2003). Segundo Luz (2003) o mercado aparente de peles para curtimento e acabamento está em expansão, comercializando cerca de 35 milhões de unidades por ano.

Para cada pele processada são gerados, em média, 12 quilos de lodos (Class \& Maia, 1994), sendo o lodo do caleiro e o lodo primário da estação de tratamento de efluentes (ETE) os gerados em maior quantidade. As características desses lodos variam muito em função do tipo de pele a ser processada, tecnologia empregada no processamento das peles e sistema de tratamento de efluentes adotado pela indústria. De maneira geral, esses resíduos se tornam altamente poluidores à medida que concentram uma elevada carga orgânica e inorgânica. O lodo do caleiro apresenta em sua composição altos teores de carbonatos, hidróxidos, sódio e sulfetos, já o lodo primário da ETE pode conter alto teor de crômio na forma trivalente, com potencial de risco biológico em função das condições de oxi-redução do meio. Devido a necessidade da indústria em se adequar às novas exigências ambientais, aliada ao avanço tecnológico no processamento de peles (separação de resíduos com crômio e reciclagem dos efluentes), o teor de crômio no lodo primário da ETE tem sido reduzido.

De acordo com a legislação ambiental vigente no país, as indústrias curtumeiras, consideradas potencialmente poluidoras, devem destinar os seus resíduos, segundo normas estaduais e/ou federais, dentro dos padrões de qualidade ambiental estabelecidos por lei (Brasil, 1981). Uma das alternativas de destino desses resíduos é o seu uso na agricultura. O potencial de utilização de lodos de curtume em áreas agrícolas 
deve-se principalmente ao elevado teor de nutrientes e potencial de neutralização da acidez do solo.

Por outro lado, o acúmulo no solo de altas concentrações de alguns elementos, como o nitrogênio, sódio e o crômio, contidos no lodo de curtume, podem proporcionar impactos negativos ao meio ambiente.

Altos teores de nitrogênio no solo, decorrentes da mineralização da fração orgânica do lodo de curtume, podem proporcionar impactos negativos, principalmente quando a mineralização não é sincronizada com a absorção pelas plantas, possibilitando sua movimentação e conseqüente contaminação das águas superficiais e subterrâneas.

Já o sódio pode causar limitações no desenvolvimento das plantas, dispersão de argilas e até dispersão da matéria orgânica, enquanto o metal pesado crômio, quando em excesso no solo, pode ser tóxico a plantas, animais e seres humanos.

A utilização do lodo do caleiro como corretivo e fertilizante do solo, bem como a dinâmica de oxi-redução do crômio adicionado ao solo por intermédio da aplicação do lodo primário da ETE com alto teor desse elemento, foram objetos de estudos de vários pesquisadores (Jahnel 1999; Castilhos et al., 1999; Castilhos et al., 2000 e Alcântara \& Camargo, 2001;). Com o avanço tecnológico e conseqüente redução no teor de crômio contido no lodo primário da ETE, surge a possibilidade da utilização em conjunto desses dois lodos em solos agrícolas. Porém, outros elementos, como o sódio, ainda são encontrados em altas concentrações nesses lodos, os quais limitam o seu uso na agricultura.

Desse modo, torna-se importante estudar o impacto decorrente da utilização em conjunto do lodo do caleiro mais o lodo primário da ETE, com teor de crômio reduzido, nos atributos biológicos e químicos de solos com características físicoquímicas diferentes (sobretudo textura) e nas plantas. Nesse contexto, o presente trabalho objetivou (i) avaliar a cinética de degradação da fração orgânica da mistura de dois lodos de curtume após aplicação em doses crescentes em três solos; (ii) avaliar as alterações microbiológicas e químicas em três solos após a aplicação de doses crescentes da mistura de dois lodos de curtume e seu efeito sobre a cultura da soja. 


\section{REVISÃO DE LITERATURA}

A possibilidade de uso de um determinado resíduo na agricultura depende das características do material, potencial como corretivo da acidez e/ou fertilizante e dos efeitos sobre o ambiente. Essas características variam muito em função da tecnologia empregada no processamento industrial e sistema de tratamento de efluentes adotado pela indústria.

Dentro desse contexto, conhecer o processo industrial de curtimento de peles torna-se importante e necessário para os estudos da viabilidade do uso agrícola desses resíduos.

\subsection{Processo industrial de curtimento de peles}

As principais etapas adotadas no processamento de peles são apresentadas a seguir: conservação das peles, operação de ribeira e curtimento (Class \& Maia, 1994).

\subsubsection{Conservação das peles}

Tem por finalidade interromper a decomposição da pele até o início do processamento. Essa operação baseia-se na desidratação da pele, que impede o desenvolvimento bacteriano e a ação enzimática. Geralmente, o cloreto de sódio $(\mathrm{NaCl})$ é o agente mais empregado na conservação das peles. A desvantagem de sua utilização consiste na alta quantidade empregada que pode chegar a $500 \mathrm{~kg} \mathrm{Mg}^{-1}$ de pele, que deverá ser eliminado durante o processamento, gerando um efluente com alta concentração de sódio (Class \& Maia, 1994). 


\subsubsection{Recuperação do sal empregado na conservação}

É realizada mediante o batimento das peles em tambores rotativos gradeados. O sal recuperado pode ser empregado novamente na salga de peles. A retirada do sal das peles tem por finalidade facilitar os processos subseqüentes e reduzir a concentração de $\mathrm{NaCl}$ nos efluentes.

\subsubsection{Operação de ribeira}

Consiste na preparação das peles para o curtimento, sendo dividida nas seguintes etapas: pré-remolho, pré-descarne, remolho, depilação e caleiro, descarne e divisão, desencalagem, purga e píquel.

Pré-remolho: Processo que visa a lavagem das peles para retirada do sal e hidratação parcial. Nessa etapa são utilizados aproximadamente $2000 \mathrm{~L}$ de água por $\mathrm{Mg}$ de pele.

Pré-descarne: Tem por finalidade retirar, restos de gordura e carne ou fibras não aproveitáveis, deixadas pelo frigorífico. O resíduo produzido nessa etapa pode ser utilizado como matéria prima para a produção de sebo.

Remolho: Visa repor o teor de água apresentado pelas peles antes da etapa de conservação, eliminação de impurezas e extração de proteínas e materiais interfibrilares. $\mathrm{O}$ volume de água utilizado pode chegar a $3000 \mathrm{~L} \mathrm{Mg}^{-1}$ de pele.

Os produtos químicos mais utilizados são: hidróxido de sódio $\left(1,0-2,0 \mathrm{~g} \mathrm{~L}^{-1}\right)$, hidróxido de amônio (1,0-3,0 $\left.\mathrm{g} \mathrm{L}^{-1}\right)$, tensoativos não iônicos (1,0-2,0 $\left.\mathrm{g} \mathrm{L}^{-1}\right)$, bactericidas derivados de carbamatos (1,0-2,0 $\mathrm{g} \mathrm{kg}^{-1}$ de pele) e enzimas proteolíticas de origem bacteriana (1,0-2,0 $\mathrm{g} \mathrm{L}^{-1}$ ) (MK Química do Brasil, 2004).

Depilação e caleiro: Nessa etapa são empregadas técnicas que visam remover os pêlos e o sistema epidérmico, bem como preparar as peles para as etapas posteriores. $\mathrm{Na}$ depilação os íons hidroxila e sulfetos, juntamente com as enzimas proteolíticas, são responsáveis pela remoção química dos pêlos. Já a etapa de caleiro é responsável pela abertura, intumescimento da estrutura fibrosa e ação sobre as gorduras, preparando a pele para o curtimento. 
Vários são os sistemas de depilação e caleiro utilizados. O mais comum, muito embora apresente graves problemas de poluição, é o cal-sulfeto. Nesse sistema, o pH fica em torno de 11,5 a 12,0 e o volume de água a ser utilizado pode chegar a $3000 \mathrm{~L}$ $\mathrm{Mg}^{-1}$ de pele .Os produtos químicos mais utilizados são: cal hidratada (20,0 a 50,0 $\mathrm{g} \mathrm{kg}^{-1}$ de pele) e sulfeto de sódio (20,0 a 40,0 $\mathrm{g} \mathrm{kg}^{-1}$ de pele) (Class \& Maia, 1994 e Barros et al., 2001).

Visando minimizar a carga de poluentes gerada no sistema cal-sulfeto, os curtumes vêm adotando a reciclagem do efluente do caleiro e substituição de parte da cal e sulfeto por outros produtos (aminas, complexo organo-fosfatado e álcalis) (MK Química do Brasil, 2004). Parte do efluente gerado nessa etapa pode ser reciclado. O lodo gerado após a reciclagem recebe o nome de lodo do caleiro.

Descarne e divisão: $O$ descarne tem por objetivo eliminar os materiais aderidos ao tecido subcutâneo e adiposo, facilitando a penetração dos produtos químicos aplicados em etapas posteriores. Nesse processo a pele sofre recortes visando aparar e remover apêndices. Em seguida, a pele é dividida em duas partes: camada superficial e inferior. O resíduo gerado nessa etapa e denominado de lodo de carnaça.

Desencalagem: Visa à remoção de substâncias alcalinas ou quimicamente combinadas depositadas nas peles. Nessa etapa são usados sais amoniacais, tais como cloreto de amônio e sulfato de amônio e sais ácidos como o bissulfito de sódio (Class \& Maia, 1994).

Purga: Processo que tem por objetivo limpar as estrutura fibrosa da pele por meio da ação de enzimas proteolíticas. As enzimas, juntamente com sulfato de amônio, bissulfito de sódio ou ácidos orgânicos fracos, neutralizam a alcalinidade das peles e retiram materiais queratinosos já degradados (Barros et al., 2001).

Píquel: Visa preparar as fibras de colágenos para uma fácil penetração dos produtos químicos utilizados no curtimento. Os produtos químicos mais utilizados no píquel são: cloreto de sódio (60,0 a 100,0 $\mathrm{g} \mathrm{kg}^{-1}$ de pele), ácido sulfúrico (10,0 a 15,0 g $\mathrm{kg}^{-1}$ de pele) e ácido fórmico (5,0 a 10,0 $\mathrm{g} \mathrm{kg}^{-1}$ de pele), podendo também ser utilizados sais de alumínio (5,0 a 10,0 $\mathrm{g} \mathrm{kg}^{-1}$ de pele). A quantidade de água utilizada nessa etapa pode chegar a $1000 \mathrm{~L} \mathrm{Mg}^{-1}$ de pele (Class \& Maia, 1994). 
Curtimento: Nessa etapa ocorre o aumento da estabilidade de todo o sistema colágeno, diminuindo a capacidade de intumescimento do mesmo, tornando a pele resistente à degradação biológica.

No processo de curtimento podem ser utilizadas substâncias de origem orgânica (taninos vegetais, sintéticos, aldeídos e parafinas sulfocloradas) ou inorgânica (sais de crômio, zircônio, alumínio e ferro). Dentre os inorgânicos, os sais de crômio trivalente são os mais utilizados, sendo o sulfato básico de crômio $\left(\mathrm{Cr}_{2}(\mathrm{OH})_{2}\left(\mathrm{SO}_{4}\right)_{2}\right)$ a forma mais comumente empregada.

A reatividade do crômio com a pele é afetada pelo pH da solução de crômio trivalente. Esse aspecto deve ser controlado durante o processo, que ocorre em duas etapas: difusão e fixação do sal de crômio trivalente. Na difusão, a pele deve ficar em meio ácido, a fim de facilitar a penetração dos sais de crômio trivalente em toda a espessura da pele. Após esse procedimento, inicia-se o aumento da alcalinidade e temperatura, fazendo com que o complexo de crômio reaja com a estrutura protéica da pele, promovendo a fixação do crômio trivalente (curtimento). Para que esse processo ocorra é necessário utilizar quantidades de sais de crômio trivalente que disponibilizem de 20,0 a 30,0 g de óxido de crômio $\left(\mathrm{Cr}_{2} \mathrm{O}_{3}\right)$ por quilo de pele. Após o curtimento ao crômio o couro assim obtido é chamado de "wet-blue", devido à sua consistência e coloração.

Em curtumes mais modernos toda a etapa de curtimento é realizada em tambores rotativos separados. O efluente gerado, contendo crômio, pode ser reciclado e reutilizado no processo de curtimento ou conduzido para a ETE, onde é tratado em separado. O tratamento consiste na precipitação do crômio em meio básico, formando hidróxido de crômio trivalente $\left(\mathrm{Cr}(\mathrm{OH})_{3}\right)$, o qual origina um resíduo sólido com alto teor de crômio.

Enxugamento: Operação que visa reduzir a umidade do couro de aproximadamente $70 \%$ para $50 \%$. O efluente originado nessa etapa contém crômio, sendo tratado juntamente com o efluente originado no curtimento. 


\subsection{Resíduos gerados durante o processamento das peles}

O processo de transformação das peles em couro, conforme descrito anteriormente, gera uma grande quantidade de resíduos com alta concentração de produtos químicos e matéria orgânica. Os resíduos gerados durante o processamento podem ser classificados como: gasosos, líquidos e sólidos (Claas \& Maia, 1994). Na Figura 1 são apresentadas as etapas do processamento das peles e os resíduos gerados.

Resíduos gasosos: São constituídos por amônia, gás sulfídrico e subprodutos aminados. A amônia é proveniente da decomposição da parte protéica das peles. Os demais gases são produzidos durante a etapa de ribeira. $\mathrm{O}$ gás sulfídrico é considerado o mais perigoso, pois concentrações no ar, na ordem de $1000 \mathrm{mg} \mathrm{L}^{-1}$ podem causar a morte (Claas \& Maia, 1994)

Resíduos líquidos: São efluentes, compostos pelas soluções utilizadas nas etapas do processamento das peles e pelas águas de lavagem do piso e das máquinas. Em alguns curtumes os efluentes contendo crômio são tratados em separado, sendo os demais efluentes homogeneizados e conduzidos até a ETE. Passam então, por tratamentos físico-químicos (tratamento primário), dando origem ao lodo primário da ETE e a um novo efluente, que depois de tratado biologicamente (tratamento secundário) origina o lodo secundário da ETE e a água residuária, que deve ter qualidade para lançamento no meio ambiente.

Resíduos sólidos: Os resíduos sólidos gerados nas etapas do processamento das peles são: sal, aparas, carnaça e lodos. Na Tabela 1 são apresentados alguns dados gerais da quantidade dos resíduos sólidos gerados nos curtumes.

Tabela 1. Quantidades de alguns resíduos sólidos gerados no processamento de peles

\begin{tabular}{lcc}
\hline \multicolumn{1}{c}{ Resíduos } & Quantidade em $\mathrm{kg} \mathrm{Mg}^{-1}$ de pele salgada & Umidade $\left(\mathrm{g} \mathrm{kg}^{-1}\right)$ \\
\hline Sal & 60 & $300-350$ \\
Aparas caleadas e não caleadas & 120 & $600-750$ \\
Carnaça & $70-230$ & 800 \\
Aparas curtidas ao crômio & 115 & 400 \\
Lodos da ETE & $3000-5000$ & $800-980$ \\
\hline
\end{tabular}

Fonte: Claas \& Maia (1994). 


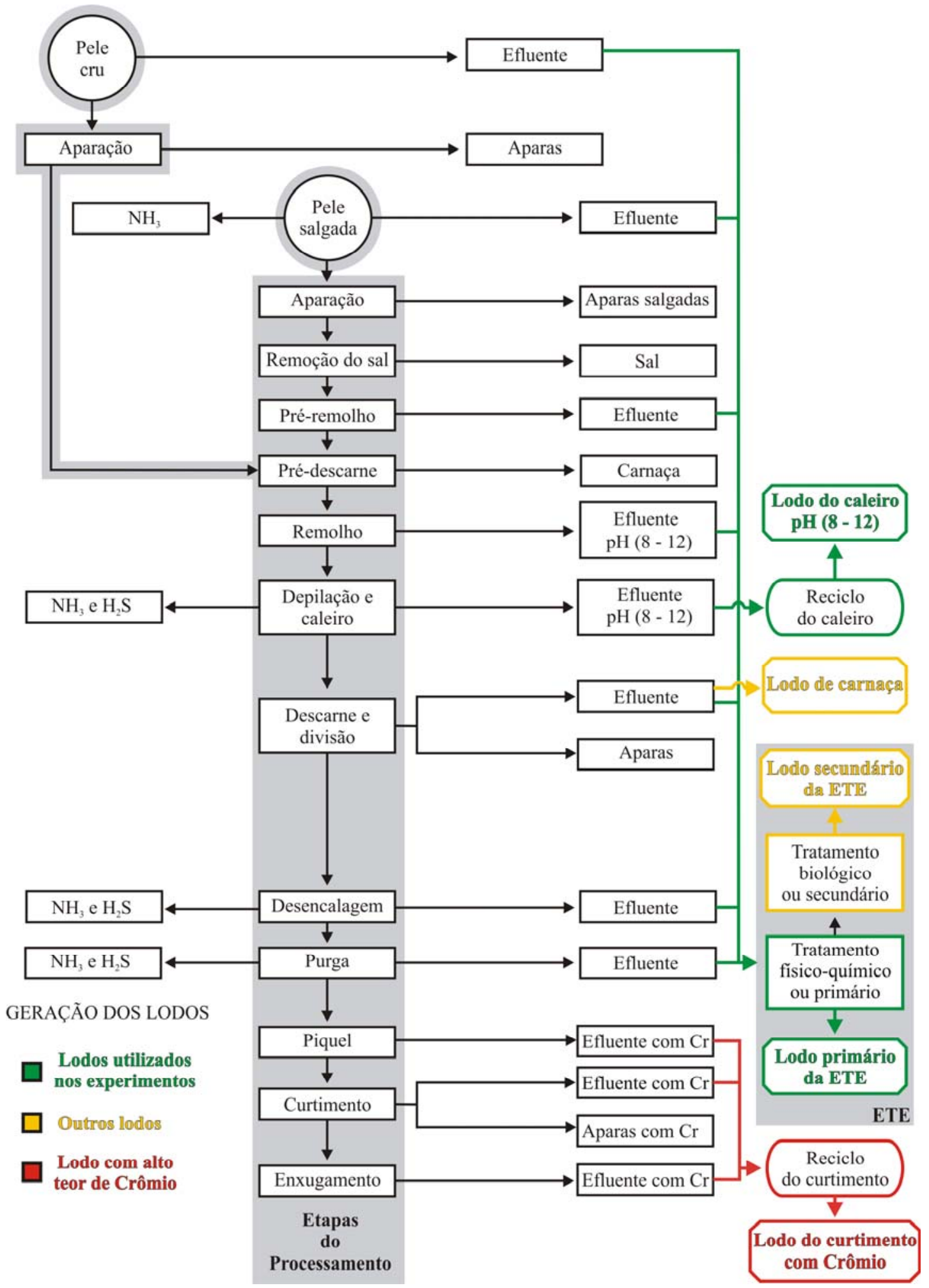

Figura 1 - Diagrama do processo de curtimento de peles e geração de resíduos em curtumes que separam os resíduos e reciclam efluentes 
O sal é gerado na etapa de remoção do conservante das peles e pode ser considerado um subproduto quando reutilizado para conservar novas peles.

As aparas são constituídas pelos recortes de peles e outras partes rejeitadas no processamento. As aparas não caleadas e caleadas são utilizadas como matéria prima na fabricação de colas de origem animal e gelatinas de uso farmacêutico ou alimentar. Já as aparas curtidas são destinadas a aterros industriais ou utilizadas pelas indústrias de calçados e vestuário na confecção de artigos.

A carnaça é originada na etapa de pré-descarne, sendo utilizada como matéria prima na fabricação de sebo, sabões e ração para a alimentação animal.

Com a necessidade da indústria em se adequar às novas exigências ambientais, aliada ao avanço tecnológico no processamento das peles (separação e reciclagem dos efluentes), pode-se, atualmente, encontrar curtumes que produzem vários tipos de lodo: do descarne, do caleiro, do curtimento, do tratamento primário da ETE e do tratamento secundário da ETE. A principal diferença entre os curtumes que reciclam e separam os efluentes dos que não utilizam dessa tecnologia, está na composição do lodo primário da ETE. Em curtumes que separam os efluentes de curtimento o teor de crômio é reduzido, como mostra a Tabela 2.

Tabela 2. Caracterização físico-química do lodo primário da ETE

\begin{tabular}{lcc}
\hline \multicolumn{1}{c}{ Parâmetros } & \multicolumn{2}{c}{ Lodo Primário da ETE } \\
& $\begin{array}{c}\text { Sem separação do efluente de } \\
\text { curtimento }\end{array}$ & $\begin{array}{c}\text { Com separação do efluente de } \\
\text { curtimento }\end{array}$ \\
\hline $\mathrm{pH}$ & 7,1 & 7,5 \\
Umidade a $65^{\circ} \mathrm{C}\left(\mathrm{g} \mathrm{kg}^{-1}\right)$ & 856,0 & 815,0 \\
Carbono orgânico $\left(\mathrm{g} \mathrm{kg}^{-1}\right)$ & 593,0 & 118,4 \\
$\mathrm{~N}$ total $\left(\mathrm{g} \mathrm{kg}^{-1}\right)$ & 34,1 & 14,1 \\
P total $\left(\mathrm{g} \mathrm{kg}^{-1}\right)$ & 2,5 & 11,4 \\
$\mathrm{~K}$ total $\left(\mathrm{g} \mathrm{kg}^{-1}\right)$ & 1,0 & 1,1 \\
Ca total $\left(\mathrm{g} \mathrm{kg}^{-1}\right)$ & 31,0 & 210,0 \\
Mg total $\left(\mathrm{g} \mathrm{kg}^{-1}\right)$ & 1,5 & 2,2 \\
Na total $\left(\mathrm{g} \mathrm{kg}^{-1}\right)$ & 5,9 & 49,6 \\
Cr total $\left(\mathrm{mg} \mathrm{kg}^{-1}\right)$ & 36000 & 1100 \\
Relação C/N & 17,4 & 9,0 \\
\hline
\end{tabular}

Fonte: ${ }^{1}$ Konrad \& Castilhos (2002); ${ }^{2}$ Lodo proveniente do Curtume Vanzella LTDA. 


\subsection{Uso do lodo de curtume na agricultura}

Os lodos de curtume são constituídos de materiais orgânicos de origem animal misturados com sais inorgânicos, sendo que alguns desses componentes são nutrientes para as plantas e microrganismos, como nitrogênio, cálcio, enxofre, fósforo, magnésio e potássio (Selbach et al., 1991).

Os lodos de curtume podem ser empregados na agricultura como corretivos da acidez do solo, pois elevam o $\mathrm{pH}$ do solo e reduzem os teores de alumínio trocável, vindo a substituir totalmente a calagem. Esse efeito deve-se à presença de quantidades significativas de carbonatos, principalmente o de cálcio, e hidróxidos, oriundos da etapa de depilação e caleiro (Selbach et al., 1991). Konrad \& Castilhos (2002), em estudo das alterações químicas de um Planossolo (textura média) decorrente da adição de lodo do caleiro, verificaram que a aplicação de $20,5 \mathrm{Mg} \mathrm{ha}^{-1}$ (base seca) elevou o $\mathrm{pH}$ de 4,5 para 5,5 e aumentou em seis vezes o teor de cálcio do solo.

Elevação do $\mathrm{pH}$ e neutralização do Al trocável do solo também foram observados em estudos a campo com lodo de curtume por Ferreira et al. (2003). Segundo esses autores, a adição de 21,25 $\mathrm{Mg} \mathrm{ha}^{-1}$ (base seca) de lodo de curtume elevou o pH do solo de 4,9 para 6,0 e diminuiu o teor de Al trocável de 6,0 para 2,3 $\mathrm{mmol}_{\mathrm{C}} \mathrm{dm}^{-}$

${ }^{3}$, produzindo estatisticamente o mesmo efeito do tratamento que recebeu $3,4 \mathrm{Mg} \mathrm{ha}^{-1}$ de calcário com PRNT de 100\%.

Ferreira et al. (2003) consideraram que o aporte de magnésio, potássio e fósforo ao solo, por meio do lodo de curtume, pode ser desconsiderado quando aplicado em quantidades adequadas para atingir $\mathrm{pH} 6$, tendo em vista o baixo teor desses elementos no lodo.

\subsubsection{Mineralização do nitrogênio}

Devido a grande quantidade de matéria orgânica de origem protéica contida nos lodos de curtume, esses podem ser empregados na agricultura como fonte de nitrogênio, sendo sua disponibilidade dependente da mineralização (Companhia de Tecnologia de Saneamento Ambiental-CETESB, 1999). Nesse sentido, deve-se observar que o nitrogênio contido na fração orgânica do lodo de curtume não é prontamente 
disponível para as plantas, requerendo um conhecimento prévio da sua cinética no solo, a fim de assegurar que a quantidade de resíduo aplicada irá disponibilizar quantidade suficiente de nitrogênio para as plantas.

A mineralização do nitrogênio no solo (amonificação e nitrificação) é essencialmente microbiológica. As duas fases apresentam a mesma importância, isso porque as plantas são capazes de absorver o nitrogênio tanto na forma amoniacal quanto na forma nítrica (Andrade et al., 1994). A amonificação é o processo de conversão do nitrogênio orgânico em amônio. Esse processo é relativamente lento e não requer a presença de microrganismos específicos, podendo ser realizado por muitos microrganismos quimiorganotróficos, tanto em condições aeróbicas como anaeróbicas.

A nitrificação é considerada de vital importância para a produtividade primária, ciclagem de nutrientes, tratamento de resíduos e qualidade das águas (Victória, et al., 1992). Os microrganismos que atuam nessa etapa podem ser quimiolitotróficos ou quimiorganotróficos. Os primeiros são os principais responsáveis pela nitrificação em solos, sendo os únicos diretamente ligados à nitrificação em ambientes naturais. São bactérias gram negativas da família Nitrobacteriaceae, que oxidam o amônio $\left(\mathrm{NH}_{4}{ }^{+}\right)$a nitrato $\left(\mathrm{NO}_{3}{ }^{-}\right)$, via nitrito $\left(\mathrm{NO}_{2}^{-}\right)$(Andrade et al., 1994).

A quantidade de nitrogênio mineralizado no solo em um dado período é dependente da temperatura, disponibilidade de água, taxa de reabastecimento de oxigênio, pH, quantidade e natureza dos resíduos vegetais (Stanford \& Smith, 1972). Nos solos tratados com resíduos orgânicos, a mineralização do nitrogênio, é altamente dependente da composição do resíduo, sobretudo relação C/N (Mengel, 1996), e das características química e física do solo que receberá o resíduo (Chae \& Tabatabai, 1986).

No lodo de curtume, a relação $\mathrm{C} / \mathrm{N}$ normalmente é muito baixa, da ordem de 7/1 (Ferreira et al., 2003) ou até menor do que 5/1 (Barajas-Aceves \& Dendooven, 2001). Desse modo, espera-se que haja uma rápida mineralização do nitrogênio orgânico do lodo logo nos primeiros dias após a aplicação no solo (Feigin et al., 1991). Assim, por meio da nitrificação, o $\mathrm{NH}_{4}{ }^{+}$existente no lodo, bem como o que derivou da amonificação, é normalmente oxidado a $\mathrm{NO}_{2}^{-}$e rapidamente a $\mathrm{NO}_{3}{ }^{-}$. A amônia $\left(\mathrm{NH}_{3}\right)$, derivada da mineralização, torna-se susceptível à volatilização em condições alcalinas e 
o $\mathrm{NO}_{3}{ }^{-}$no solo pode ser desnitrificado em condições anaeróbias $\left(2 \mathrm{NO}_{3}{ }^{-} \rightarrow 2 \mathrm{NO}_{2}{ }^{-} \rightarrow 2\right.$ $\mathrm{NO} \rightarrow \mathrm{N}_{2} \mathrm{O} \rightarrow \mathrm{N}_{2}$ ). Conseqüentemente, em condições aeróbias, a rápida mineralização do N-orgânico contido nos resíduos pode acarretar em acúmulo de nitrato no solo.

O nitrato é fracamente adsorvido no solo, percolando com mais facilidade no perfil, vindo a contaminar as águas subterrâneas. Essa contaminação pode ser mais acentuada em áreas onde ocorrem solos arenosos. Altas concentrações de nitrato na água utilizada para consumo humano $\left(>10 \mathrm{mg} \mathrm{L}^{-1}\right)$ podem causar metahemoglobinemia, doença que dificulta o transporte de oxigênio na corrente sangüínea (Meurer at al., 2000).

Por outro lado, a mineralização do nitrogênio contido na fração orgânica dos lodos é essencial para o aproveitamento desse elemento pelas plantas. Aquino Neto (1998), estudando durante 132 dias a mineralização, de lodos de curtume adicionados a dois Latossolos, um com textura argilosa e outro com textura média, observou a mineralização de $35 \%$ do nitrogênio total do lodo de caleiro (sem crômio), enquanto que a mineralização do lodo do decantador primário contendo crômio $\left(1735,0 \mathrm{mg} \mathrm{kg}^{-1}\right)$ foi de apenas 4,8\%. Segundo o autor, a menor mineralização do nitrogênio orgânico contido no lodo do decantador primário com crômio, pode estar relacionada à possível formação de complexos entre o metal e o material orgânico contido no lodo, dificultado assim a ação dos microrganismos amonificadores.

Em geral, os teores de nitrogênio total aumentam nos solos, quando aplicado lodo de curtume. Konrad \& Castilhos (2002) observaram um aumento de 10\% no teor de nitrogênio total do solo 40 dias após a aplicação de $20,50 \mathrm{Mg} \mathrm{ha}^{-1}$ de lodo do caleiro, em relação ao tratamento que recebeu $260 \mathrm{~kg} \mathrm{ha}^{-1}$ de nitrogênio via uréia. Segundo esses autores, a quantidade de nitrogênio mineralizado foi suficiente para manter a cultura de milho utilizada no experimento

\subsubsection{Crômio}

Muitos trabalhos foram realizados tendo por objetivo avaliar a dinâmica de oxi-redução do crômio em solos que receberam lodo de curtume com alta concentração 
desse elemento (Castilhos et al., 1999; Castilhos et al., 2000; Alcântara \& Camargo, 2001).

Os estados de oxidação do crômio variam de -2 a +6 , mas apenas o +3 e o +6 são relativamente estáveis no ambiente. Nos resíduos de curtume o crômio apresenta-se na forma trivalente $\left(\mathrm{Cr}^{3+}\right)$, sendo o estado de oxidação mais estável no solo, apresentando baixa solubilidade e mobilidade com o aumento do pH (Alcântara \& Camargo, 2001), sendo sua completa precipitação a partir do pH 5,5 (Bartlett \& kimble, 1976).

$\mathrm{O}$ acúmulo constante no solo de $\mathrm{Cr}^{3+}$ associado a determinadas condições, como a presença de manganês em formas oxidadas $\left(\mathrm{Mn}^{3+}\right.$ e $\left.\mathrm{Mn}^{4+}\right)$, pode promover a sua oxidação para formas hexavalentes (Milacic \& Stupar, 1995), de alta solubilidade e mobilidade, caracteristicamente tóxicas e mutagênicas para os animais superiores, plantas e microrganismos. Entretanto, essa oxidação pode ser lenta e em pequenas quantidades quando o $\mathrm{Cr}^{3+}$ é adicionado ao solo via lodo de curtume ou juntamente com uma fonte de matéria orgânica (Aquino Neto \& Camargo, 2000 e Jahnel et al., 1999)

Aquino Neto \& Camargo (2000) verificaram a formação de $\mathrm{Cr}^{6+}$ no Latossolo

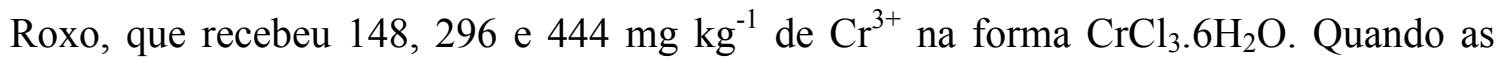
mesmas quantidades de $\mathrm{Cr}^{3+}$ foram aplicadas via lodo de curtume não houve formação de $\mathrm{Cr}^{6+}$. Segundo os autores, a não formação de $\mathrm{Cr}^{6+}$ pode estar ligada ao fato de $\mathrm{o} \mathrm{Cr}^{3+}$ encontrar-se em formas insolúveis ou complexadas com as proteínas provenientes das peles.

$\mathrm{O} \mathrm{Cr}^{3+}$, quando adicionado juntamente com uma fonte de matéria orgânica pode ter seu efeito tóxico reduzido. Segundo Jahnel et al. (1999) a aplicação de $50 \mathrm{mg}$ $\mathrm{kg}^{-1}$ de $\mathrm{Cr}^{3+}$ na forma $\mathrm{K}_{2} \mathrm{Cr}_{2} \mathrm{O}_{7}$ a uma amostra de solo argiloso reduziu o número de bactérias totais do solo em relação à testemunha (apenas solo). Quando a mesma quantidade foi aplicada juntamente com bagaço de cana $\left(10 \mathrm{~g} \mathrm{~kg}^{-1}\right)$ e composto orgânico $\left(30 \mathrm{~g} \mathrm{~kg}^{-1}\right)$, essa redução não foi observada. De acordo com os autores, a presença simultânea de bagaço de cana e de composto diminui o efeito prejudicial do $\mathrm{Cr}^{3+}$, por favorecer o crescimento de maior número de microrganismos, ou por diminuir a 
disponibilidade de $\mathrm{Cr}^{3+}$ em função do aumento da capacidade de troca catiônica e/ou pela formação de complexos de crômio com a matéria orgânica.

A absorção de crômio pelas plantas está associada às características da cultura e do meio onde se desenvolve. Nesse sentido, o estado de oxidação do elemento no solo exerce importante papel. Na forma hexavalente, o crômio apresenta-se como cromato, solúvel que penetra facilmente através da membrana celular, possuindo uma ação tóxica aguda por ser um forte agente oxidante. O crômio trivalente, por sua vez, é solúvel somente a valores de $\mathrm{pH}$ menores que cinco, ou quando complexado com moléculas orgânicas de baixo peso molecular, que possuem pouca mobilidade através da membrana celular (Bartlett \& James, 1988).

Uma pequena translocação do crômio absorvido pelas raízes para a parte aérea das plantas tem sido constatada em diversos estudos. Lahouti \& Peterson (1979) cultivando diversas plantas em solução nutritiva com ${ }^{51} \mathrm{Cr}^{3+}$ ou ${ }^{51} \mathrm{Cr}^{6+}$, verificaram que aproximadamente $98 \%$ do elemento absorvido permaneceu retido nas raízes. Situação semelhante foi observada por Shewry \& Peterson (1974), após aplicarem ${ }^{51} \mathrm{CrO}_{4}{ }^{2-}$, quando notaram que apenas $1 \%$ do isótopo absorvido foi translocado para a parte aérea.

A textura do solo também está relacionada com a absorção de crômio pelas plantas. Figliolia et al. (1992) além de constatar o aumento no teor de crômio nas folhas da alface cultivada em solos que receberam lodo de curtume (200 $\mathrm{mg} \mathrm{kg}^{-1} \mathrm{de}^{\mathrm{Cr}^{3+}}$ ), observaram que plantas cultivadas em solo de textura arenosa apresentaram uma concentração de crômio $\left(11,1 \mathrm{mg} \mathrm{kg}^{-1}\right)$ 2,5 vezes superior à do solo de textura média $\left(4,4 \mathrm{mg} \mathrm{kg}^{-1}\right)$.

\subsubsection{Salinização, sodicidade e condutividade elétrica}

Todos os solos contêm uma mistura de sais solúveis, dentre os quais, muitos são essenciais ao desenvolvimento de plantas, enquanto outros não são prejudiciais quando em baixas concentrações. A salinização dos solos é conseqüência da elevação na concentração de sais no solo, a qual pode prejudicar o desenvolvimento das plantas. A utilização na agricultura de resíduos com alta concentração de sais é um dos fatores que colaboram para a salinização dos solos. 
Os sais solúveis do solo são constituídos principalmente pelos cátions $\mathrm{Ca}^{+2}$, $\mathrm{Mg}^{2+}$ e $\mathrm{Na}^{+}$e pelos ânions $\mathrm{Cl}^{-}$e $\mathrm{SO}_{4}{ }^{2-}$. $\mathrm{O}$ cátion $\mathrm{K}^{+}$e os ânions $\mathrm{HCO}_{3}{ }^{2-}, \mathrm{CO}_{3}{ }^{2-}$ e $\mathrm{NO}_{3}{ }^{-}$são encontrados geralmente em quantidades menores (Richards, 1954).

Os solos afetados por sais podem ser classificados como salinos (apresentam altas concentrações de sais solúveis), sódicos (com altas concentrações de sódio trocável) e salino-sódicos (apresentam altas concentrações de sais e de sódio trocável) (Bohnen et al., 2000). Os principais parâmetros utilizados para caracterizar os solos salinos são a condutividade elétrica (CE), percentual de sódio trocável (PST), pH e razão de adsorção de sódio (RAS).

Segundo o Laboratório de Salinidade dos Estados Unidos (Richards, 1954) os solos afetados por sais podem ser classificados em:

\footnotetext{
$>$ Solo não sódico e não salino $-\mathrm{CE}<4 \mathrm{dS} \mathrm{m}^{-1} / \mathrm{PST}<15 \% / \mathrm{pH}<8,5$

$>$ Solo salino $-\mathrm{CE}>4 \mathrm{dS} \mathrm{m}^{-1} / \mathrm{PST}<15 \% / \mathrm{pH}<8,5$

$>$ Solo sódico $-\mathrm{CE}<4 \mathrm{dS} \mathrm{m}^{-1} / \mathrm{PST}>15 \% / \mathrm{pH}>8,5$

$>$ Solo salino-sódico $-\mathrm{CE}>4 \mathrm{dS} \mathrm{m}^{-1} / \mathrm{PST}>15 \% / \mathrm{pH}<8,5$
}

Solos tratados com lodo de curtume podem adquirir características salinas, sódicas ou até mesmo salino-sódicas, em decorrência da elevada concentração de sais contidos no lodo e da dose de lodo aplicada. Vários pesquisadores têm constatado que a adição de lodo de curtume aos solos eleva a condutividade elétrica e o teor de sódio no solo (Jahnel, 1997; Costa et al., 2001; Kronrad \& Castilhos, 2002 e Aquino Neto \& Camargo, 2000). Aquino Neto \& Camargo, (2000) concluíram que o crômio contido no lodo de curtume não foi responsável pelo efeito fitotóxico observado nas plantas de alface cultivadas em Latossolo Vermelho amarelo, sendo esse efeito atribuído ao aumento na salinidade do solo, em decorrência da aplicação de $57 \mathrm{Mg} \mathrm{ha}^{-1}$ (base seca) de lodo de curtume, que causou um aumento na CE de 1,07 para 4,14 $\mathrm{dS} \mathrm{m}^{-1}$.

A grande proporção de sódio nos sítios de troca dos minerais de argila ocasiona expansão e dispersão das argilas do solo. $\mathrm{O}$ sódio pode ocupar os espaços porosos do solo (Irvine \& Reid, 2001), conseqüentemente, ocorrer a deterioração das 
estruturas do solo e das propriedades de infiltração de água e aeração, podendo afetar o crescimento vegetal (Raij, 1991 e Rengasamy \& Olsson, 1991).

\subsubsection{Efeito na microbiota}

A possibilidade de diminuição da biodegradação dos lodos de curtume no solo está intimamente relacionada com a atividade microbiana, a qual pode ser inibida pelas altas concentrações de sais, elevados valores de $\mathrm{pH}$ e toxicidade do crômio.

O uso de parâmetros microbiológicos como indicadores da poluição do solo tem sido recomendado devido ao contato íntimo estabelecido entre os microrganismos e os microambientes do solo. Segundo Domsch et al. (1983), é importante considerar, em primeira instância, os efeitos do estresse ao qual as comunidades microbianas são naturalmente submetidas, incluindo as flutuações na temperatura, os extremos de potencial hídrico, os extremos de $\mathrm{pH}$, distúrbios físicos do solo, mudanças nas trocas

gasosas, decréscimo no suprimento de nutrientes e a presença de predadores e antagonistas. Qualquer alteração em um ou vários desses fatores pode afetar os microrganismos do solo.

Dessa forma, a utilização combinada de vários parâmetros microbiológicos, tais como a cinética da degradação de compostos orgânicos, carbono da biomassa microbiana, número mais provável de microrganismos amonificadores, número mais provável de bactérias e fungos totais, fixação biológica do nitrogênio e atividade enzimática, tem mostrado ser um procedimento mais adequado para avaliar a poluição do solo do que aqueles que seriam obtidos por meio da análise de um único parâmetro (Brookes, 1995).

A degradação da fração orgânica contida nos resíduos pode ser medida principalmente de três maneiras: quantificação de carbono liberado na forma de gás carbônico $\left(\mathrm{CO}_{2}\right)$; estimativa do carbono da biomassa formada com base na eficiência de conversão microbiológica dos substratos em degradação e empregando modelos cinéticos de degradação (Moreira \& Siqueira, 2002).

A medida do carbono liberado pela oxidação de compostos orgânicos até $\mathrm{CO}_{2}$ por organismos aeróbicos do solo, que utilizam $\mathrm{O}_{2}$ como aceptor final de elétrons, é 
denominada de respirometria. Essa metodologia é muito empregada na avaliação da velocidade de degradação dos compostos orgânicos.

Passianoto et al. (2001) avaliaram a atividade microbiana por meio da respiração e não constataram inibição do processo respiratório, mesmo quando aplicados $60 \mathrm{Mg} \mathrm{kg}^{-1}$ de lodo de curtume contendo crômio. Esse fato também foi observado por Jahnel (1997), o qual constatou uma correlação direta entre dose de lodo aplicada e produção de $\mathrm{CO}_{2}$. Porém, Ross et al. (1981), ao observarem diminuição da produção de $\mathrm{CO}_{2}$ em solos que receberam crômio trivalente $\left(100 \mathrm{mg} \mathrm{kg}^{-1}\right)$ na forma de sal, especularam que uma das possíveis causas seria a capacidade que esse elemento tem de unir os compostos orgânicos, formando complexos de baixa disponibilidade para a microbiota, sofrendo assim uma degradação muito lenta no solo.

O carbono da biomassa microbiana também é utilizado para avaliar a degradação e o acúmulo de matéria orgânica. A biomassa microbiana representa uma reserva considerável de nutrientes, os quais são continuamente assimilados durante os ciclos de crescimento dos diferentes organismos que compõem o ecossistema. Conseqüentemente, solos que mantêm um alto conteúdo de biomassa microbiana são capazes não somente de estocar, mas também de ciclar mais nutrientes no sistema (Stenberg, 1999).

Segundo Brookes (1995), a relação entre o carbono da biomassa microbiana e o conteúdo de carbono orgânico total do solo pode servir de parâmetro para um determinado ecossistema. Desse modo, quando esse parâmetro for modificado como, por exemplo, em decorrência de mudanças climáticas ou de manejo, teríamos uma indicação preliminar de que alguma mudança no ecossistema ocorreu.

Em geral, a adição de resíduos orgânicos ao solo induz um aumento transiente da biomassa, medida pela quantidade de carbono oriundo das células microbianas. Jahnel (1997) observou um aumento no teor de carbono da biomassa em função da aplicação de doses de lodo de curtume com alto teor de crômio. Já Ferreira et al. (2003) não constataram diferença significativa no teor de carbono da biomassa, quando aplicaram $42 \mathrm{Mg} \mathrm{ha}^{-1}$ de lodo de curtume com crômio, a campo, em um Argissolo de textura média. 
A biomassa microbiana é composta por vários grupos de microrganismos, os quais estão em constante interação com o ecossistema. A introdução de resíduos no sistema pode alterar com maior ou menor intensidade alguns grupos funcionais, sem, no entanto, alterar a biomassa microbiana total. Portanto, a quantificação dos diferentes grupos de microrganismos existente no solo também pode ser utilizada na avaliação do impacto do uso de resíduos na agricultura.

Selbach et al. (1991) observaram um aumento, ao longo do tempo, no número de bactérias, fungos e actinomicetos em solos tratados com lodo de curtume contendo crômio. Resultados semelhantes foram encontrados por Castilhos et al. (2000), em que a adição de até $60 \mathrm{Mg} \mathrm{ha}^{-1}$ de lodo de curtume contendo crômio proporcionou um aumento significativo no número de bactérias, fungos e actinomicetos. Segundo esses autores, os resultados podem ser atribuídos a elevação do $\mathrm{pH}$ do solo para próximo de seis e ao aporte de matéria orgânica proporcionado pela adição do lodo ao solo. 


\section{MATERIAL E MÉTODOS}

Os experimentos foram instalados em laboratório e casa de vegetação localizados nas dependências do Departamento de Solos e Nutrição de Plantas, da Escola Superior de Agricultura Luiz de Queiroz/USP, em Piracicaba - SP.

\subsection{Caracterização dos solos}

Foram utilizadas amostras da camada superficial $(0-20 \mathrm{~cm}$ de profundidade) de três solos classificados segundo a Empresa Brasileira de Pesquisa AgropecuáriaEMBRAPA (1999b) como: Nitossolo Vermelho eutroférrico típico (NVef) com textura muito argilosa, proveniente do município de Rolândia (PR), Latossolo Vermelho Amarelo distrófico típico (LVAd) com textura argilosa, proveniente do município de Sinop (MT) e Neossolo Quartzarênico órtico típico (RQo) com textura arenosa, proveniente do município de Piracicaba (SP). Nesse trabalho, as amostras dos solos serão denominadas respectivamente de NVef (M.Argiloso), LVAd (Argiloso) e RQo (Arenoso).

As amostras dos solos coletados foram secas ao ar, peneiradas (malha $2 \mathrm{~mm}$ ), homogeneizadas e então, foram obtidas amostras de terra fina seca ao ar (TFSA), sendo submetidas às análises químicas e granulométricas. Foram empregadas relações solo:solução de 1:10 (massa:volume) para as determinações analíticas de $\mathrm{H}+\mathrm{Al}, \mathrm{Al}, \mathrm{Ca}$, $\mathrm{Mg}, \mathrm{K}, \mathrm{Na}$ e $\mathrm{P}$ e 1:2,5 (m:v) para as determinações de $\mathrm{pH}$ e $\mathrm{S}$. O pH foi determinado por potenciometria, em solução de $\mathrm{CaCl}_{2} 0,01 \mathrm{~mol} \mathrm{~L}^{-1}$. O carbono orgânico, $\mathrm{H}+\mathrm{Al}, \mathrm{S}_{-} \mathrm{SO}_{4}$, $\mathrm{Cu}, \mathrm{Zn}, \mathrm{Mn}$, e Fe total foram determinados conforme métodos descritos em Raij et al. (2001) e P, Ca, Mg, Na, K e Al trocáveis conforme EMBRAPA (1999a). As frações 
areia, silte e argila foram determinadas empregando-se o método da pipeta (Camargo et al., 1986). Os resultados das análises encontram-se na Tabela 3.

Tabela 3. Caracterização química e granulométrica dos solos estudados

\begin{tabular}{|c|c|c|c|}
\hline Variáveis & NVef (M. Argiloso) & LVAd (Argiloso) & RQo (Arenoso) \\
\hline $\mathrm{pH}\left(\mathrm{CaCl}_{2}\right)$ & 4,7 & 3,9 & 4,2 \\
\hline Carbono orgânico $\left(\mathrm{g} \mathrm{kg}^{-1}\right)$ & 20,8 & 36,2 & 4,6 \\
\hline $\mathrm{S}-\mathrm{SO}_{4}\left(\mathrm{mg} \mathrm{kg}^{-1}\right)$ & 26,8 & 19,8 & 2,5 \\
\hline P (Mehlich I) $\left(\mathrm{mg} \mathrm{kg}^{-1}\right)$ & 10,0 & 3,4 & 3,1 \\
\hline $\mathrm{K}\left(\mathrm{mmol}_{\mathrm{c}} \mathrm{kg}^{-1}\right)$ & 17,0 & 2,5 & 1,3 \\
\hline $\mathrm{Na}\left(\mathrm{mmol}_{\mathrm{c}} \mathrm{kg}^{-1}\right)$ & 4,7 & 0,6 & 0,0 \\
\hline $\mathrm{Ca}\left(\mathrm{mmol}_{\mathrm{c}} \mathrm{kg}^{-1}\right)$ & 52,7 & 1,7 & 6,2 \\
\hline $\operatorname{Mg}\left(\mathrm{mmol}_{\mathrm{c}} \mathrm{kg}^{-1}\right)$ & 19,0 & 1,5 & 2,8 \\
\hline $\mathrm{Al}\left(\mathrm{mmol}_{\mathrm{c}} \mathrm{kg}^{-1}\right)$ & 2,0 & 18,0 & 3,7 \\
\hline $\mathrm{H}+\mathrm{Al}\left(\mathrm{mmol}_{\mathrm{c}} \mathrm{kg}^{-1}\right)$ & 72,0 & 114,4 & 19,5 \\
\hline $\mathrm{Cu}\left(\mathrm{mg} \mathrm{kg}^{-1}\right)$ & 16,6 & 1,1 & 1,1 \\
\hline $\mathrm{Zn}\left(\mathrm{mg} \mathrm{kg}^{-1}\right)$ & 4,0 & 0,5 & 0,6 \\
\hline $\operatorname{Mn}\left(\mathrm{mg} \mathrm{kg}^{-1}\right)$ & 244,0 & 1,21 & 7,4 \\
\hline $\mathrm{Fe}\left(\mathrm{mg} \mathrm{kg}^{-1}\right)$ & 23,23 & 282,0 & 18,3 \\
\hline $\mathrm{SB}\left(\mathrm{mmol}_{\mathrm{c}} \mathrm{kg}^{-1}\right)$ & 93,4 & 6,3 & 10,3 \\
\hline CTC $\left(\mathrm{mmol}_{\mathrm{c}} \mathrm{kg}^{-1}\right)$ & 165,4 & 120,7 & 29,8 \\
\hline Saturação por bases (\%) & 56,5 & 5,2 & 34,5 \\
\hline Argila (\%) & 73,0 & 56,0 & 10,0 \\
\hline Silte $(\%)$ & 23,0 & 4,0 & 2,0 \\
\hline Areia (\%) & 4,0 & 40,0 & 88,0 \\
\hline
\end{tabular}

\subsection{Caracterização do lodo de curtume}

O lodo de curtume utilizado nos experimentos foi composto de uma mistura na proporção de 1:1 do lodo do caleiro, gerado na etapa de depilação e caleiro, mais o lodo primário da ETE, resultante da precipitação dos efluentes gerados no processo, com exceção dos efluentes que contém $\mathrm{Cr}$ (Figura 1). Esses lodos foram coletados uma única vez no Curtume Vanzella, localizado no município de Rolândia (PR). O pH e a condutividade elétrica (CE) foram medidos diretamente na amostra de lodo de curtume. 
A umidade foi determinada por aquecimento a $65^{\circ} \mathrm{C}$ até peso constante. Os demais atributos foram determinados de acordo com métodos descritos em Kiehl (1985), sendo apenas o Cr total determinado segundo Abreu et al. (2001). Os resultados, expressos em matéria seca a $65^{\circ} \mathrm{C}$, encontram-se na Tabela 4 .

Tabela 4. Caracterização físico-química do lodo de curtume

\begin{tabular}{|c|c|}
\hline Variáveis & Concentração \\
\hline $\mathrm{pH}^{\mathrm{a}}$ & 11,8 \\
\hline $\left.\mathrm{CE}(\mathrm{dS} \mathrm{m})^{-1}\right)^{\mathrm{a}}$ & 27,6 \\
\hline Umidade a $65^{\circ} \mathrm{C}\left(\mathrm{g} \mathrm{kg}^{-1}\right)$ & 854,8 \\
\hline Carbono total $\left(\mathrm{g} \mathrm{kg}^{-1}\right)$ & 181,8 \\
\hline Carbono orgânico $\left(\mathrm{g} \mathrm{kg}^{-1}\right)$ & 177,0 \\
\hline $\mathrm{N}$ total $\left(\mathrm{g} \mathrm{kg}^{-1}\right)$ & 28,2 \\
\hline $\mathrm{N}$ amoniacal $\left(\mathrm{g} \mathrm{kg}^{-1}\right)$ & 9,6 \\
\hline $\mathrm{N}$ nítrico $\left(\mathrm{g} \mathrm{kg}^{-1}\right)$ & 0,4 \\
\hline Relação C/N & 6,4 \\
\hline $\mathrm{S}$ total $\left(\mathrm{g} \mathrm{kg}^{-1}\right)$ & 12,4 \\
\hline P total $\left(\mathrm{g} \mathrm{kg}^{-1}\right)$ & 3,3 \\
\hline Ca total $\left(\mathrm{g} \mathrm{kg}^{-1}\right)$ & 210,1 \\
\hline Na total $\left(\mathrm{g} \mathrm{kg}^{-1}\right)$ & 59,9 \\
\hline $\operatorname{Mg}$ total $\left(\mathrm{g} \mathrm{kg}^{-1}\right)$ & 2,1 \\
\hline $\mathrm{K}$ total $\left(\mathrm{g} \mathrm{kg}^{-1}\right)$ & 0,6 \\
\hline Mn total $\left(\mathrm{mg} \mathrm{kg}^{-1}\right)$ & 2307 \\
\hline Fe total $\left(\mathrm{mg} \mathrm{kg}^{-1}\right)$ & 944 \\
\hline Zn total $\left(\mathrm{mg} \mathrm{kg}^{-1}\right)$ & 48 \\
\hline $\mathrm{Cu}$ total $\left(\mathrm{mg} \mathrm{kg}^{-1}\right)$ & 14 \\
\hline Cr total $\left(\mathrm{mg} \mathrm{kg}^{-1}\right)$ & 798 \\
\hline
\end{tabular}

${ }^{a}$ Medidos diretamente no lodo de curtume.

\subsection{Doses de lodo de curtume utilizadas nos experimentos}

As doses de lodo utilizadas no NVef (muito argiloso) e no LVAd (argiloso) foram equivalentes a $0,6,12,24,36 \mathrm{Mg} \mathrm{ha}^{-1}$ (base seca) e para o RQo (arenoso) as doses utilizadas foram equivalentes a $0,3,6,12,24 \mathrm{Mg} \mathrm{ha}^{-1}$. Essas doses foram determinadas 
após incubação prévia dos solos com doses de lodo de curtume variando de 5 a $80 \mathrm{Mg}$ $\mathrm{ha}^{-1}$, que teve por objetivo avaliar as alterações químicas dos solos, sobretudo do $\mathrm{pH}$, porcentual de sódio trocável (PST) e saturação por $\mathrm{Ca}, \mathrm{Mg}$ e $\mathrm{K}$ trocáveis (dados não apresentados). De acordo com os resultados obtidos na incubação prévia, as doses de 24 $\mathrm{Mg} \mathrm{ha}^{-1}$ para o NVef (muito argiloso) e LVAd (argiloso) e de $6 \mathrm{Mg}^{-1}$ para o RQo (arenoso) seriam suficientes para elevar o $\mathrm{pH}$ dos solos a 6,0, sendo que, doses acima desses valores foram utilizadas com o intuito de verificar o efeito do excesso de sódio no solo. As quantidades de alguns elementos, fornecidas pelo lodo de curtume em cada uma das cinco doses estão apresentadas na Tabela 5.

Tabela 5. Quantidades de alguns elementos adicionados via doses de lodo de curtume

\begin{tabular}{lccccc}
\hline \multicolumn{1}{c}{ Elementos } & \multicolumn{5}{c}{ Doses de lodo de curtume $\left(\mathrm{Mg} \mathrm{ha}^{-1}\right)^{\mathrm{a}}$} \\
& 3 & 6 & 12 & 24 & 36 \\
\hline Carbono total $\left(\mathrm{g} \mathrm{kg}^{-1}\right)$ & 0,3 & 0,5 & 1,1 & 2,2 & 3,3 \\
$\mathrm{~N}$ total $\left(\mathrm{kg} \mathrm{ha}^{-1}\right)$ & 84,7 & 169,4 & 338,8 & 677,7 & 1016,5 \\
$\mathrm{~N}$ inorgânico $\left(\mathrm{kg} \mathrm{ha}^{-1}\right)$ & 30,1 & 60,2 & 120,3 & 240,7 & 361,0 \\
$\mathrm{~S}$ total $\left(\mathrm{kg} \mathrm{ha}^{-1}\right)$ & 37,2 & 74,4 & 148,8 & 297,5 & 446,3 \\
P total $\left(\mathrm{kg} \mathrm{ha}^{-1}\right)$ & 9,9 & 19,8 & 39,7 & 79,4 & 119,1 \\
Ca total $\left(\mathrm{kg} \mathrm{ha}^{-1}\right)$ & 630,2 & 1260,3 & 2520,7 & 5041,3 & 7562,0 \\
Na total $\left(\mathrm{kg} \mathrm{ha}^{-1}\right)^{\mathrm{b}}$ & 179,7 & 359,5 & 718,9 & 1437,9 & 2156,8 \\
Mg total $\left(\mathrm{kg} \mathrm{ha}^{-1}\right)$ & 6,2 & 12,4 & 24,8 & 49,6 & 74,4 \\
$\mathrm{~K}$ total $\left(\mathrm{kg} \mathrm{ha}^{-1}\right)$ & 1,7 & 3,4 & 6,9 & 13,7 & 20,6 \\
Mn total $\left(\mathrm{kg} \mathrm{ha}^{-1}\right)$ & 6,9 & 13,8 & 27,7 & 55,4 & 83,1 \\
Fe total $\left(\mathrm{kg} \mathrm{ha}^{-1}\right)$ & 2,8 & 5,7 & 11,3 & 22,6 & 34,0 \\
Zn total $\left(\mathrm{kg} \mathrm{ha}^{-1}\right)$ & 0,1 & 0,3 & 0,6 & 1,2 & 1,7 \\
Cr total $\left(\mathrm{mg} \mathrm{kg}^{-1}\right)^{\mathrm{c}}$ & 1,2 & 2,4 & 4,8 & 9,6 & 14,4 \\
\hline
\end{tabular}

a Doses calculadas considerando-se o volume de solo de um hectare com $20 \mathrm{~cm}$ de profundidade e densidade do solo igual a um; ${ }^{b}$ Segundo norma P 4.233 da CETESB, (1999), o limite máximo permitido de $\mathrm{Na}$ aplicado anualmente em solos arenosos e silto-arenosos é $400 \mathrm{~kg} \mathrm{ha}^{-1} \mathrm{e}$ para solos orgânicos, siltosos, silto-argilosos e argilosos é $1000 \mathrm{~kg} \mathrm{ha}^{-1}$; ${ }^{\mathrm{c}}$ Segundo norma P 4.233 da CETESB, (1999), o limite máximo permitido de Cr total no solo é $500 \mathrm{mg} \mathrm{kg}^{-1}$. 


\subsection{Estudo 1: Avaliação da degradação do lodo de curtume}

Com o objetivo de avaliar a cinética de degradação da fração orgânica em três amostras de solos tratados com lodo de curtume, foram instalados três experimentos de respirometria, sendo cada experimento constituído de um solo mais suas respectivas doses de lodo. A degradação da fração orgânica do lodo de curtume foi avaliada por meio da quantificação indireta do carbono liberado na forma de $\mathrm{CO}_{2}\left(\mathrm{C}_{-} \mathrm{CO}_{2}\right)$, segundo método descrito por Anderson (1982).

Os experimentos foram conduzidos por um período de 105 dias, no escuro e em sala climatizada com temperatura constante de $28^{\circ} \mathrm{C}$. O delineamento experimental, para cada solo, foi inteiramente casualizado, em fatorial completo $5 \times 21$ (cinco doses e 21 épocas de avaliação) com três repetições. O correspondente a cada dose de lodo foi aplicado em $200 \mathrm{~g}$ de terra, que foram acondicionados em pote respirométrico de $1,5 \mathrm{~L}$, provido de tampa vedante. A umidade do solo foi corrigida para $60 \%$ da capacidade máxima de retenção. Cada pote respirométrico recebeu um frasco contendo solução de $\mathrm{NaOH} 0,5 \mathrm{~mol} \mathrm{~L}^{-1}$, que foi trocada periodicamente conforme as épocas de avaliação, sendo estas aos 1, 2, 3, 4, 5, 6, 7, 8, 9, 10, 11, $12,13,14,15,20,25,40,60,80$ e 105 dias de incubação. Em cada época de avaliação, os frascos contendo solução de $\mathrm{NaOH}$ receberam $1 \mathrm{~mL}$ da solução de $\mathrm{BaCl}_{2} 4 \mathrm{~mol} \mathrm{~L}^{-1}$ e 3 gotas de fenolftaleína, sendo posteriormente titulados com solução padronizada de $\mathrm{HCl} 0,5 \mathrm{~mol} \mathrm{~L}^{-1}$.

\subsubsection{Análise dos dados coletados}

Os dados foram interpretados na forma de $\mathrm{C}-\mathrm{CO}_{2}$ acumulado, até 105 dias de incubação, descontando-se o valor da testemunha (dose 0), atribuindo-se essa diferença à degradação do carbono aplicado via resíduo (C-degradado). Tais valores foram submetidos à análise de variância e regressão não-linear por meio do programa estatístico SAS Versão 8.02 (1999). Todas as análises foram realizadas individualmente para cada solo.

$\mathrm{O}$ modelo não linear utilizado foi o de cinética química de primeira ordem: C-degradado $=\mathrm{C}_{\mathrm{o}} \cdot\left(1-\mathrm{e}^{\mathrm{kt}}\right)$, sendo C-degradado (carbono degradado no tempo t; em mg $100 \mathrm{~g}^{-1}$ ), $\mathrm{C}_{\mathrm{o}}$ (carbono potencialmente mineralizável do resíduo, na dose considerada; em mg $100 \mathrm{~g}^{-1}$ ), $\mathrm{k}$ (constante de velocidade da reação de degradação do carbono do lodo de curtume; em dias ${ }^{-1}$ ) e t (tempo; em dias). A meia-vida de degradação, que é correspondente ao tempo necessário para 
que ocorra a degradação de metade do carbono potencialmente mineralizável $\left(\mathrm{C}_{\mathrm{o}}\right)$ durante os 105 dias de incubação, foi obtida segundo a equação: Ln 2 / k. A taxa de degradação foi calculada no final do período de incubação por meio da equação: Tx. degradação $=\mathrm{C}$ degradado ×100) / C-adicionado, sendo Tx. Degradação (taxa de degradação do carbono adicionado via dose do lodo de curtume; em \%), C-degradado (diferença entre $\mathrm{C}-\mathrm{CO}_{2}$ liberado acumulado no tratamento e na testemunha; em $\mathrm{mg} 100 \mathrm{~g}^{-1}$ ) e C-adicionado (quantidade de carbono adicionado via dose do lodo de curtume; em mg $100 \mathrm{~g}^{-1}$ ).

\subsection{Estudo 2: Alterações nos atributos biológicos e químicos dos solos e efeito sobre a cultura da soja após aplicação de doses crescentes de lodo de curtume}

Com o objetivo de avaliar as alterações nos atributos microbiológicos e químicos, em três solos, após a aplicação de doses crescentes de lodo de curtume e o efeito sobre a cultura da soja, foram instalados três experimentos em casa de vegetação, sendo cada experimento constituído por um solo mais suas respectivas doses de lodo.

O delineamento experimental, para cada experimento, foi inteiramente casualizado, em fatorial $5 \times 4$ (cinco doses e quatro épocas de avaliação) com quatro repetições. Cada parcela experimental foi constituída por um vaso plástico contendo duas plantas cultivadas em $4 \mathrm{~kg}$ de solo. Foi realizada uma fertilização mineral de base diferenciada para cada solo, tendo em vista que a quantidade de alguns nutrientes nos solos não atenderia às necessidades da cultura (Tabela 6).

Tabela 6. Quantidades de nutrientes adicionados aos solos via fertilização mineral

\begin{tabular}{lcc}
\multicolumn{1}{c}{ Amostras de Solos } & $\begin{array}{c}\text { Fósforo } \\
\text { (superfosfato simples) }\end{array}$ & $\begin{array}{c}\text { Fertilização Mineral } \\
\text { Potássio }\end{array}$ \\
\hline (cloreto de potássio)
\end{tabular}


Após a adição das doses de lodo, os vasos receberam água destilada até atingirem $70 \%$ da capacidade de retenção. Decorridos sete dias, cada parcela recebeu seis sementes de soja (variedade Embrapa 48), pré-germinadas (1 $\mathrm{cm}$ de radícula) e inoculadas com bactérias do gênero Bradyrhizobium (Produto comercial Nitragin ${ }^{\circledR}$ ). A emergência completa das plantas ocorreu sete dias após o plantio, período em que se realizou o desbaste, deixando apenas duas plantas por vaso. Durante a condução do experimento os vasos receberam, quando necessário, água destilada em quantidade suficiente para manter o desenvolvimento das plantas. Em cada época de avaliação foram desmontadas 20 parcelas de cada experimento, sendo separadas parte aérea das plantas, raiz e terra. As épocas de avaliação estão descritas na Tabela 7.

Tabela 7. Épocas de avaliação das parcelas

\begin{tabular}{cccc}
\hline Época & Dias após a emergência & $\begin{array}{c}\text { Estádio fenológico } \\
1\end{array}$ & Descrição do estádio fenológico \\
\hline $1^{\mathrm{a}}$ Época & 10 & $\mathrm{~V}_{2}$ & $1^{\mathrm{a}}$ folha trifoliolar completamente \\
& & $\mathrm{R}_{2}$ & expandida \\
$2^{\mathrm{a}}$ Época & 44 & $\mathrm{R}_{4}$ & Pleno florescimento \\
$3^{\mathrm{a}}$ Época & 67 & $\mathrm{R}_{8}$ & Pleno enchimento de grãos \\
$4^{\text {a Época }}$ & 103 & & Plena maturação \\
\hline
\end{tabular}

${ }^{1}$ Segundo Fehr et al. (1971).

\subsubsection{Avaliação da massa de matéria seca da parte aérea e produtividade de grãos}

A parte aérea das plantas foi seca em estufa com circulação forçada de ar à temperatura de $60^{\circ} \mathrm{C}$ até atingir massa constante para determinação da matéria seca (MSPA). Na ultima época de avaliação as vagens foram separadas, sendo os grãos secos em estufa com circulação forçada de ar à temperatura de $60^{\circ} \mathrm{C}$ até atingir massa constante para determinação da produtividade.

\subsubsection{Avaliação da massa de matéria seca e número de nódulos}

$\mathrm{Na}$ segunda e terceira época de avaliação os nódulos foram separados das raízes ainda úmidas e colocados para secar em estufa com circulação forçada de ar à 
temperatura de $60^{\circ} \mathrm{C}$, até atingir massa constante para determinação da matéria seca (MS Nódulos) e número de nódulos ( $\mathrm{N}^{\mathrm{o}}$ Nódulos).

\subsubsection{Teor de sódio e crômio na parte aérea das plantas}

A matéria seca da parte aérea das plantas da segunda época de avaliação (florescimento) foi moída em moinho tipo "Wiley", equipado com peneira de malha 20 mesh para determinação das concentrações de $\mathrm{Na}$ e $\mathrm{Cr}$, segundo metodologias descritas em Malavolta et al. (1997).

As determinações de $\mathrm{Na}$ e $\mathrm{Cr}$ foram realizadas mediante digestão nítricoperclórica e leitura por fotometria de emissão de chama para o $\mathrm{Na}$ e espectrofotometria de emissão atômica com plasma de argônio para o Cr.

\subsubsection{Avaliações microbiológicas}

Foram separados $200 \mathrm{~g}$ de terra úmida de cada parcela para serem utilizados nas análises microbiológicas, sendo $10 \mathrm{~g}$ secos em estufa à temperatura de $105^{\circ} \mathrm{C}$ para determinação da umidade.

\subsubsection{Estimativa do número mais provável de bactérias totais nos solos}

Foram misturados $10 \mathrm{~g}$ de solo em $90 \mathrm{~mL}$ de solução salina $\mathrm{NaCl}\left(8,5 \mathrm{~g} \mathrm{~L}^{-1}\right)$, sendo as suspensões diluídas até $10^{-10}$ (diluições sucessivas). A estimativa do número mais provável (NMP) de bactérias foi realizada segundo método de plaqueamento por gotas descrito por Jahnel et al. (1999). O meio de cultura utilizado foi o ágar nutriente, sendo esse composto de: $1000 \mathrm{~mL}$ de água destilada, $10 \mathrm{~g}$ de ágar, $3 \mathrm{~g}$ de extrato de carne, $10 \mathrm{~g} \mathrm{NaCl}$ e $5 \mathrm{~g}$ de peptona.

Inoculou-se $0,1 \mathrm{~mL}$ de cinco suspensões (diluições sucessivas), respectivamente, em $0,9 \mathrm{~mL}$ do meio de cultura, o qual foi depositado na forma de gotas de 0,04 $\mathrm{mL}$ (quatro repetições) em placa de Petri esterilizada. As placas de Petri foram vedadas e mantidas em sala climatizada com temperatura constante de $28^{\circ} \mathrm{C}$ por 48 horas. Após o período de incubação, foi verificado, com auxilio de uma lupa, o número de gotas positivas, ou seja, aquelas em que ocorreu o crescimento de pelo menos uma 
colônia bacteriana. A partir dos resultados obtidos em cada uma das diluições, e com auxilio de uma tabela de probabilidade de ocorrência (tabela de Cochran, Andrade et al.,1994) estimou-se o NMP de bactérias, o qual foi dividido por 0,04 (volume da gota) a fim de obter o NMP de bactérias totais dos solos.

\subsubsection{Estimativa do número mais provável de microrganismos amonificadores}

A estimativa do número mais provável (NMP) de microrganismos amonificadores foi realizada segundo metodologia sugerida por Andrade et al. (1994), modificada quanto ao meio de cultura utilizado, sendo este composto de: $1000 \mathrm{~mL}$ de água destilada, 0,5 $\mathrm{g} \mathrm{K}_{2} \mathrm{HPO}_{4}, 0,2 \mathrm{~g} \mathrm{MgSO}_{4} .7 \mathrm{H}_{2} \mathrm{O}, 10 \mathrm{~g} \mathrm{NaCl}, 0,2 \mathrm{~g}$ asparagina, 0,2 $\mathrm{mg}$ $\mathrm{ZnSO}_{4} .7 \mathrm{H}_{2} \mathrm{O}, 0,074 \mathrm{mg} \mathrm{CuSO}_{4} .5 \mathrm{H}_{2} \mathrm{O}, 0,025 \mathrm{mg} \mathrm{NaMoO}{ }_{4} \cdot 2 \mathrm{H}_{2} \mathrm{O}, 2,86 \mathrm{mg} \mathrm{H}_{3} \mathrm{BO}_{3}$ e $5 \mathrm{mg}$ de Fe-EDTA.

Foram utilizadas quatro suspensões diluídas (as mesmas da determinação do NMP de bactérias), sendo inoculado $1 \mathrm{~mL}$ de cada suspensão em quatro tubos de ensaio (repetições) contendo $5 \mathrm{~mL}$ do meio de cultura autoclavado. Os tubos permaneceram por seis dias em sala climatizada com temperatura constante de $28^{\circ} \mathrm{C}$. A presença de amônia foi determinada pela formação de cor marrom aveludado quando adicionado o reagente de Nessler. Após o período de incubação, foi verificado, o número de tubos de ensaio positivos, ou seja, aqueles em que o meio de cultura apresentou amônia. A partir dos resultados obtidos em cada uma das diluições e com auxílio de uma tabela de probabilidade de ocorrência (tabela de Cochran, Andrade et al.,1994), estimou-se o NMP de microrganismos amonificadores.

\subsubsection{Carbono da biomassa microbiana}

O carbono da biomassa microbiana foi determinado pelo método de fumigação e extração descrito por Vance et al. (1987). Foram pesadas duas sub-amostras de solo de $10 \mathrm{~g}$ e colocadas em frascos de vidro. Uma das sub-amostras sofreu fumigação com clorofórmio por um período de 24 horas e a outra sub-amostra não sofreu fumigação (controle). Ambas sub-amostras, sofreram extração do carbono com $40 \mathrm{~mL}$ de $\mathrm{K}_{2} \mathrm{SO}_{4}$

$\left(0,5 \mathrm{~mol} \mathrm{~L}^{-1}\right)$. As suspensões foram filtradas com papel de filtro qualitativo $\mathrm{n}^{\mathrm{o}} 42$. $\mathrm{O}$ 
carbono orgânico contido nos extratos filtrados foi oxidado por íons de $\mathrm{K}_{2} \mathrm{Cr}_{2} \mathrm{O}_{7}$ em meio fortemente ácido. A concentração de carbono na biomassa microbiana foi obtida por titulação do excesso de $\mathrm{K}_{2} \mathrm{Cr}_{2} \mathrm{O}_{7}$ com solução de $\mathrm{Fe}\left(\mathrm{NH}_{4}\right)_{2}\left(\mathrm{SO}_{4}\right) \cdot 6 \mathrm{H}_{2} \mathrm{O}$, usando difenilamina sulfanato de bário como indicador. $\mathrm{O}$ cálculo do carbono da biomassa microbiana foi efetuado por meio da fórmula: C-biomassa $=\left(\mathrm{C}_{\mathrm{f}}{ }^{-} \mathrm{C}_{\mathrm{nf}}\right) / \mathrm{k}_{\mathrm{c}}$, sendo $\mathrm{C}_{\mathrm{f}}(\mathrm{C}$ da sub-amostra fumigada), $\mathrm{C}_{\mathrm{nf}}$ ( $\mathrm{C}$ da sub-amostra não fumigada) e $\mathrm{k}_{\mathrm{c}}$ (fator de correção, $0,33)$.

\subsubsection{Análise química dos solos}

Foram separados $300 \mathrm{~g}$ de terra úmida de cada parcela para serem utilizados nas análises químicas, sendo $100 \mathrm{~g}$ congelados para posterior análise de $\mathrm{N}^{-\mathrm{NH}_{4}}{ }^{+} \mathrm{e} \mathrm{N}$ $\mathrm{NO}_{3}{ }^{-}$, o restante da terra foi secada ao ar, peneirada (malha $2 \mathrm{~mm}$ ) e homogeneizada, para a obtenção da amostra de terra fina seca ao ar (TFSA).

O nitrogênio foi extraído com $\mathrm{KCl}\left(2 \mathrm{~mol} \mathrm{~L}^{-1}\right)$ na relação 1:10 m: v (5g de solo úmido $+50 \mathrm{~mL}$ de $\mathrm{KCl}$ ), sendo o $\mathrm{N}-\mathrm{NH}_{4}{ }^{+}$e $\mathrm{N}^{-\mathrm{NO}_{3}}{ }^{-}$determinados, respectivamente, por condutividade e colorimetria, mediante o emprego de um sistema de análise de injeção em fluxo contínuo (FIA), conforme metodologia descrita por Alves et al. (1994).

$\mathrm{O} \mathrm{pH}$ foi determinado por potenciometria em solução de $\mathrm{CaCl}_{2} 0,01 \mathrm{~mol} \mathrm{~L}^{-1}$ na relação 1:2,5 (m:v) e a condutividade elétrica em extrato aquoso na relação 1:1 m:v (30g de terra $+30 \mathrm{~mL}$ água destilada-deionizada) com leitura após uma hora de agitação vigorosa e filtragem em papel de filtro qualitativo $n^{\circ} 42$.

Foram empregadas relações solo:solução de 1:10 (m:v) para as determinações analíticas de $\mathrm{H}+\mathrm{Al}, \mathrm{Ca}, \mathrm{Mg}, \mathrm{K}$ e $\mathrm{Na}$. As concentrações de $\mathrm{H}+\mathrm{Al}$ (acidez total) foram determinadas por titulação com solução padronizada de $\mathrm{NaOH} 0,025 \mathrm{~mol} \mathrm{~L}^{-1}$ de extratos de TFSA obtidos com solução de $\mathrm{Ca}\left(\mathrm{CH}_{3}-\mathrm{COO}\right)_{2} \quad 0,5 \mathrm{~mol} \mathrm{~L}^{-1}$ a $\mathrm{pH} 7,0$. As concentrações trocáveis de $\mathrm{Al}$ (acidez trocável), $\mathrm{Ca}$ e $\mathrm{Mg}$ foram determinadas em extratos de TFSA obtidos com solução de $\mathrm{KCl} 1,0 \mathrm{~mol} \mathrm{~L}^{-1}$. Foram determinadas as concentrações de $\mathrm{Al}$ trocável por titulação com solução padronizada de $\mathrm{NaOH}$ 0,025 mol $\mathrm{L}^{-1}$ e as concentrações de $\mathrm{Ca}$ e $\mathrm{Mg}$ foram obtidas mediante leitura por espectrometria de absorção atômica com atomização em chama (EAA-chama). As concentrações de $\mathrm{Na}, \mathrm{K}$ 
e P foram determinadas em extratos de TFSA obtidos com solução de Mehlich-1 (HCl $0,05 \mathrm{~mol} \mathrm{~L}^{-1}+\mathrm{H}_{2} \mathrm{SO}_{4} 0,0125 \mathrm{~mol} \mathrm{~L}^{-1}$ ), mediante leitura por EEC para $\mathrm{Na}$ e $\mathrm{K}$.

O crômio total foi determinado segundo metodologia descrita por Abreu et al. (2001). Essa análise foi realizada apenas na primeira época de avaliação e em dois tratamentos de cada solo, sendo uma amostra composta pelas repetições do tratamento que não recebeu lodo (dose 0 ), e a outra composta pelas repetições do tratamento que recebeu a maior dose de lodo.

\subsubsection{Análise estatística}

Devido ao efeito deletério e conseqüente perda da interação solo-lodo-planta, foi desconsiderado os dados resultantes do tratamento que recebeu a dose $24 \mathrm{Mg} \mathrm{ha}^{-1}$, no RQo (Arenoso).

Os dados coletados foram submetidos às análises de variância e comparação de médias, regressão e correlação por meio do sistema estatístico SAS Versão 8.02 (1999). Todas as análises foram realizadas individualmente para cada solo.

A fim de se obter homogeneidade da variância, os dados relativos à massa seca de nódulos foram transformados em $1 /(\mathrm{x}+0,5)^{1 / 2}$ antes de serem submetidos à análise de variância e comparação de médias e os dados de NMP de microrganismos amonificadores e $\mathrm{N}$-mineral $\left(\mathrm{NH}_{4}{ }^{+}+\mathrm{NO}_{3}{ }^{-}\right)$foram transformados em log (x) antes de serem submetidos à análise de regressão. As transformações seguiram metodologia de Box-Cox, indicadas pelo sistema estatístico SAS Versão 8.02 (1999). 


\section{RESULTADOS E DISCUSSÃO}

\subsection{Estudo 1: Avaliação da degradação do lodo de curtume}

\subsubsection{Carbono liberado na forma de $\mathrm{CO}_{2}$ e taxa de degradação}

A quantidade de $\mathrm{C}-\mathrm{CO}_{2}$ acumulado até 105 dias aumentou em função da dose de lodo de curtume aplicada, independentemente do tipo de solo, não ocorrendo inibição do processo respiratório em nenhuma das doses utilizadas (Figura 2). As diferenças verificadas entre as quantidades de $\mathrm{C}-\mathrm{CO}_{2}$ liberadas nos tratamentos que receberam doses de lodo e nos que não receberam (testemunhas - dose 0), indicam a contribuição positiva dos resíduos na atividade microbiana edáfica.

Em geral, a atividade microbiana foi mais intensa nos primeiros 15 a 20 dias de incubação, ocorrendo decréscimo posterior (Figura 2). Esse comportamento pode ser atribuído à degradação inicial do carbono orgânico prontamente oxidável, cuja exaustão conduz à redução dos fluxos de $\mathrm{C}-\mathrm{CO}_{2}$, como mostrado no trabalho de Andrade et al. (2004), em que o autor encontrou forte correlação entre compostos protéicos presentes em lodos de esgoto e as fases iniciais de degradação $\left(\mathrm{C}-\mathrm{CO}_{2}\right.$ liberado).

Segundo Castilhos et al. (2000) e Jahnel (1997), a maior liberação de C-CO em solos tratados com lodo de curtume não se deve apenas à incorporação de matéria orgânica e nutrientes, mas também ao efeito corretivo e à ação inoculante do lodo de curtume, que possui microrganismos adaptados ao meio e atuantes na degradação dos resíduos. 

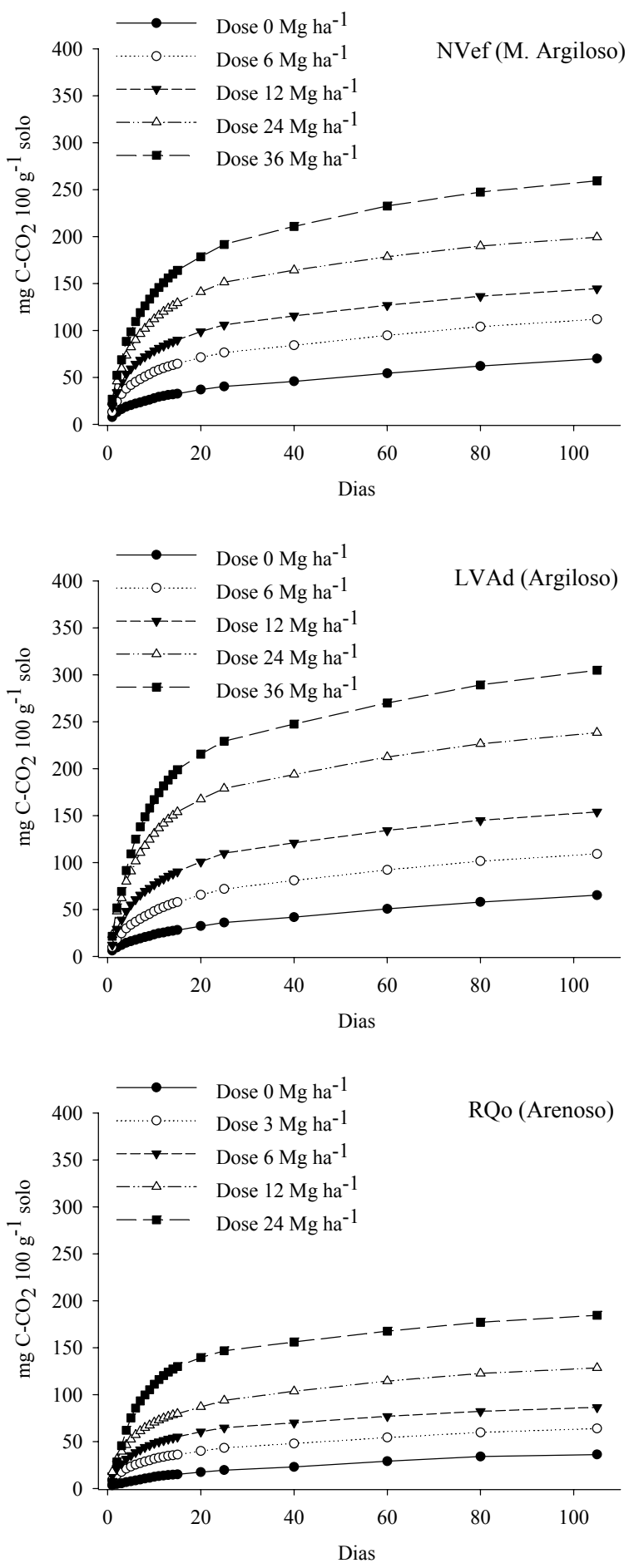

Figura 2 - Quantidade média de C- $\mathrm{CO}_{2}$ acumulado durante 105 dias de incubação, em três solos tratados com doses crescentes de lodo de curtume 
Verificou-se que os valores médios das taxas de degradação, usando os resultados obtidos para as doses 6,12 e $24 \mathrm{Mg} \mathrm{ha}^{-1}$ (Tabela 8), comuns aos três solos, foram: 68\% para o NVef (M.Argiloso); 80\% para o LVAd (Argiloso) e 82\% para o RQo (Arenoso). Esses valores estão muito acima de outros encontrados na literatura para lodos de curtume, entre 8 e 16\% em 240 dias de incubação (Konrad \& Castilhos, 2001), para lodos de esgoto, entre 7 e 25\% em 70 dias de incubação (Pires et al., 2002 e Andrade, 2004) e para a torta de filtro de cana-de-açúcar, igual a 32\% em 70 dias de incubação (Santos et al., 2002).

Barajas-Aceves \& Dendooven (2001), ao estudarem a degradação do carbono em diferentes solos que receberam $12 \mathrm{Mg} \mathrm{ha}^{-1}$ (base seca) de lodo de curtume com crômio (6690 m k kg ${ }^{-1}$ ), obtiveram um valor médio da taxa de degradação igual a 31\% em 70 dias de incubação. Segundo esses autores a taxa de degradação foi diferente para cada solo estudado, sugerindo que essa diferença fosse causada pela diversidade microbiana mais ou menos ativa de cada solo. No presente estudo, diferenças também foram verificadas entre os solos.

A taxa de degradação do lodo de curtume variou entre 58 e 101\%. Taxas de degradação elevadas devem-se, principalmente a baixa relação $\mathrm{C} / \mathrm{N}$ e composição da fração orgânica. Andrade (2004), ao estudar a cinética de degradação de quatro biossólidos, em dose correspondente a $40 \mathrm{Mg} \mathrm{ha}^{-1}$ e com relação $\mathrm{C} / \mathrm{N}$ nos resíduos inferior a 12, encontrou taxas de degradação variando entre 7,16 e 22,09\% e valores de meia-vida entre 11 e 33 dias. Segundo o autor, essas diferenças podem estar relacionadas com a matéria orgânica recalcitrante decorrente do processo biológico e de estabilização da carga orgânica, à que foram submetidos ainda na estação de tratamento.

Nos três solos estudados, o valor da taxa de degradação diminuiu com o aumento da dose. A diminuição na taxa de degradação pode estar relacionada com o aumento do conteúdo orgânico adicionado, suplantando a capacidade de degradação dos microrganismos do solo (Wong et al., 1998), o que tem sido observado em trabalhos da literatura com o uso de lodos de esgoto (Mattiazzo et al., 1998 e Pires et al., 2002). Contudo, para o RQo (Arenoso), a adição de $6 \mathrm{Mg} \mathrm{ha}^{-1}$ gerou uma taxa de degradação média superior a 100\% (Tabela 8), indicando que, para esse solo e dose, o lodo de 
curtume pode ter provocado um estímulo aos microrganismos decompositores, os quais, além de consumir todo o carbono adicionado via lodo, também podem ter degradado a matéria orgânica nativa do solo (MOS), o que se denomina de positive priming effect ou efeito "priming" positivo.

Tabela 8. Valor do carbono adicionado via lodo de curtume, média do $\mathrm{C}-\mathrm{CO}_{2}$ em 105 dias de incubação, média do carbono degradado e média da taxa de degradação, segundo os solos estudados

\begin{tabular}{|c|c|c|c|c|}
\hline \multirow[b]{2}{*}{$\begin{array}{l}\text { Doses de Lodo } \\
\qquad\left(\mathrm{Mg} \mathrm{ha}^{-1}\right)\end{array}$} & \multirow[b]{2}{*}{$\begin{array}{l}\text { Adicionando } \\
\left(\mathrm{mg} \mathrm{C} 100 \mathrm{~g}^{-1}\right)\end{array}$} & \multicolumn{2}{|l|}{ Carbono } & \multirow[b]{2}{*}{$\begin{array}{c}\text { Tx. Degradação }{ }^{1,2} \\
(\%)\end{array}$} \\
\hline & & 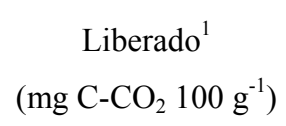 & 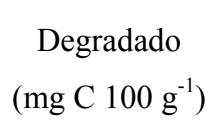 & \\
\hline \multicolumn{5}{|c|}{ NVef (M. Argiloso) } \\
\hline 0 & - & $69,98( \pm 2,58)$ & - & - \\
\hline 6 & 54,54 & $111,97( \pm 0,35)$ & 41,99 & $76,99( \pm 0,64)$ \\
\hline 12 & 109,08 & $144,53( \pm 0,55)$ & 74,55 & $68,34( \pm 0,48)$ \\
\hline 24 & 218,16 & $199,31( \pm 1,54)$ & 129,32 & $59,28( \pm 0,70)$ \\
\hline 36 & 327,24 & $259,34( \pm 1,46)$ & 189,36 & $57,87( \pm 0,14)$ \\
\hline \multicolumn{5}{|c|}{ LVAd (Argiloso) } \\
\hline 0 & - & $65,21( \pm 0,50)$ & - & - \\
\hline 6 & 54,54 & $109,20( \pm 0,22)$ & 43,99 & $80,66( \pm 0,40)$ \\
\hline 12 & 109,08 & $153,99( \pm 1,56)$ & 88,78 & $81,39( \pm 1,43)$ \\
\hline 24 & 218,16 & $238,41( \pm 0,70)$ & 173,20 & $79,39( \pm 0,32)$ \\
\hline 36 & 327,24 & $304,93( \pm 0,51)$ & 239,72 & $73,26( \pm 0,16)$ \\
\hline \multicolumn{5}{|c|}{ RQo (Arenoso) } \\
\hline 0 & - & $36,20( \pm 0,06)$ & - & - \\
\hline 3 & 27,27 & $63,82( \pm 1,34)$ & 27,62 & $101,28( \pm 4,89)$ \\
\hline 6 & 54,54 & $86,40( \pm 1,98)$ & 50,20 & $92,04( \pm 3,46)$ \\
\hline 12 & 109,08 & $128,47( \pm 0,49)$ & 92,27 & $84,59( \pm 0,45)$ \\
\hline 24 & 218,16 & $184,48( \pm 0,92)$ & 148,28 & $67,97( \pm 0,42)$ \\
\hline
\end{tabular}

${ }^{1}$ Média $\left( \pm\right.$ desvio padrão); ${ }^{2}$ Tx. degradação $(\%)=(\mathrm{C}$-degradado $\times 100) / \mathrm{C}$ adicionado via lodo.

Segundo revisão realizada por Kuzyakov et al. (2000), as causas, mecanismos e fontes que geram esse efeito ainda não estão totalmente elucidadas. No entanto, os autores 
citam que a adição de $\mathrm{N}$, principalmente na forma amoniacal, bem como de substâncias orgânicas facilmente biodegradáveis, aceleram a mineralização da MOS, em função da redução da relação $\mathrm{C} / \mathrm{N}$ da $\mathrm{MOS}$ ou por cometabolismo, respectivamente. Nesse sentido, o lodo utilizado no presente estudo poderia potencialmente promover o chamado efeito priming positivo, uma vez que o material orgânico do lodo é relativamente de fácil decomposição, o que se confirma por meio das altas taxas de degradação (Tabela 8), além de apresentar expressiva quantidade do total de $\mathrm{N}$ do resíduo sob forma amoniacal, cerca de $35 \%$ (Tabela 4 ).

$\mathrm{O}$ crômio na forma trivalente $\left(\mathrm{Cr}^{3+}\right)$, presente no lodo de curtume, parece não ter influenciado a degradação do carbono aplicado via resíduo, provavelmente pelo fato de encontrar-se em baixa concentração, quando comparado com outros lodos de curtume que não separam os efluentes que contêm crômio, nos quais, podem ser encontrados até $36000 \mathrm{mg} \mathrm{kg}{ }^{-1}$ (Konrad \& Castilhos, 2002). Ou ainda, pela possibilidade do $\mathrm{Cr}^{3+}$ encontrar-se complexado com a matéria orgânica do resíduo, mesmo quando presente em altas concentrações (Aquino Neto \& Camargo, 2000). Esses resultados também foram observados por outros autores (Ferreira et al, 2003; Castilhos et al., 2000 e Jahnel, 1997).

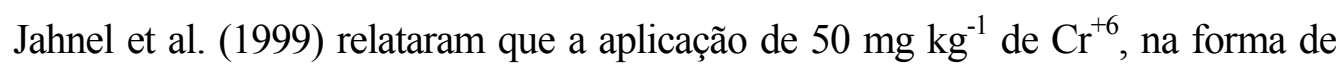
$\mathrm{K}_{2} \mathrm{Cr}_{2} \mathrm{O}_{7}$ a uma amostra de solo argiloso reduziu o número total de bactérias no solo em relação à testemunha, enquanto que essa mesma dose de $\mathrm{Cr}^{+6}$, quando também foi adicionado bagaço de cana $\left(10 \mathrm{~g} \mathrm{~kg}^{-1}\right)$ e composto orgânico $\left(30 \mathrm{~g} \mathrm{~kg}^{-1}\right)$, não proporcionou tal redução.

\subsubsection{Cinética química da degradação do carbono orgânico}

Com relação à cinética de degradação, os dados de $\mathrm{C}-\mathrm{CO}_{2}$ se ajustaram ao modelo de primeira ordem (Tabela 9). Os valores de $\mathrm{C}_{\mathrm{o}}$ aumentaram com o carbono aplicado via doses de lodo para todos os solos, enquanto que os valores da constante de velocidade de degradação $(\mathrm{k})$ tenderam a diminuir com a dose nos solos de textura muito argilosa e arenosa, não mostrando tendência clara no LVAd (Argiloso) (Tabela 9). 
Tabela 9. Parâmetros de cinética química e meia-vida de degradação obtidos a partir dos ajustes dos dados de $\mathrm{C}-\mathrm{CO}_{2}$ a equações de cinética química de primeira ordem

\begin{tabular}{|c|c|c|c|c|}
\hline \multirow{2}{*}{$\begin{array}{c}\text { Doses de Lodo } \\
\left(\mathrm{Mg} \mathrm{ha}^{-1}\right)\end{array}$} & \multicolumn{2}{|c|}{ C-degradado $=\mathrm{C}_{0}\left(1-\mathrm{e}^{-\mathrm{kt}}\right)$} & \multirow[b]{2}{*}{ Meia-vida (dia) } & \multirow[b]{2}{*}{$\mathrm{R}^{2}$} \\
\hline & $\mathrm{C}_{0}\left(\mathrm{mg} 100 \mathrm{~g}^{-1}\right.$ de solo $)$ & $\mathrm{k}\left(\operatorname{dia}^{-1}\right)$ & & \\
\hline \multicolumn{5}{|c|}{ NVef (M. Argiloso) } \\
\hline 6 & 38,97 & 0,1365 & 5 & $0,99^{* *}$ \\
\hline 12 & 69,70 & 0,1403 & 5 & $0,99^{* *}$ \\
\hline 24 & 121,00 & 0,1242 & 6 & $0,99^{* *}$ \\
\hline 36 & 175,40 & 0,1030 & 7 & $0,99^{* *}$ \\
\hline \multicolumn{5}{|c|}{ LVAd (Argiloso) } \\
\hline 6 & 41,58 & 0,0924 & 8 & $0,99^{* *}$ \\
\hline 12 & 82,68 & 0,1072 & 6 & $0,99^{* *}$ \\
\hline 24 & 160,40 & 0,1128 & 6 & $0,99^{* *}$ \\
\hline 36 & 221,90 & 0,1022 & 7 & $0,99^{* *}$ \\
\hline \multicolumn{5}{|c|}{ RQo (Arenoso) } \\
\hline 3 & 24,21 & 0,1827 & 4 & $0,99^{* *}$ \\
\hline 6 & 46,18 & 0,1659 & 4 & $0,99^{* *}$ \\
\hline 12 & 82,13 & 0,1311 & 5 & $0,99^{* *}$ \\
\hline 24 & 139,40 & 0,1214 & 6 & $0,99^{* *}$ \\
\hline
\end{tabular}

$\mathrm{R}^{2}=$ coeficiente de determinação; ${ }^{* *}$ Significativo $(\mathrm{p}<0,01)$.

Em função dos elevados valores de k, a meia-vida foi baixa, em média igual a seis dias, com valores variando de quatro a oito (Tabela 9). Isto significa que, ao final dos dez primeiros dias de incubação, mais da metade do $\mathrm{C}_{\mathrm{o}}$ foi liberado na forma de $\mathrm{C}$ $\mathrm{CO}_{2}$, evidenciando, assim, uma fase de rápida degradação, seguida de outra mais lenta e de estabilização dos fluxos de $\mathrm{C}-\mathrm{CO}_{2}$. Esse comportamento é comum quando se adicionam resíduos orgânicos a solos agrícolas (Sommers et al., 1979; Bernal et al., 1998; Santos et al., 2002). 


\subsection{Estudo 2: Alterações nos atributos biológicos e químicos dos solos e efeito sobre a cultura da soja após aplicação de doses crescentes de lodo de curtume}

O crômio não foi objeto de estudo do trabalho, visto que o teor desse elemento no lodo utilizado nos experimentos foi considerado baixo, quando comparado com outros lodos de curtumes que não separam os efluentes que contêm crômio, nos quais podem ser encontrado até $36000 \mathrm{mg} \mathrm{kg}^{-1}$ (Konrad \& Castilhos, 2002). Entretanto, foram realizadas algumas análises com o objetivo de avaliar a sua presença no solo e nas plantas.

Os teores de crômio total, determinado nas amostras de solo que receberam as maiores doses de lodo de curtume (primeira época de avaliação) foram, em média, 56\% menores que às quantidades adicionadas. A quantidade de crômio total adicionada pela maior dose de lodo (36 $\mathrm{Mg} \mathrm{ha}^{-1}$ ) utilizada no NVef (M. Argiloso) e LVAd (Argiloso), mostrou ser 34 vezes menor que o limite máximo permitido pela CETESB (Tabela 5). Não foi detectada a presença de crômio na matéria seca da parte das plantas de soja (limite de detecção $0,15 \mathrm{mg} \mathrm{kg}^{-1}$ ).

\subsubsection{Transformações do nitrogênio no solo}

O número mais provável de microrganismos amonificadores, determinados nas três amostras de solo e quatro épocas de avaliação, estão apresentados na Figura 3. Observase que a aplicação de doses crescentes de lodo de curtume favoreceu a multiplicação dos microrganismos amonificadores, não sendo observado efeito inibitório em nenhuma das doses estudadas. Esses resultados são análogos aos resultados obtidos no estudo da avaliação da degradação do lodo de curtume (Figura 2) no qual também não foi verificado efeito inibitório na atividade microbiana medida por respirometria.

Nos três solos estudados, o maior número de microrganismos amonificadores ocorreu logo nos primeiros dias após a adição do lodo, e o menor número de microrganismos ocorreu, em média, aos 74 dias. Comportamento semelhante foi observado para o teor de $\mathrm{N}_{-} \mathrm{NH}_{4}{ }^{+}$, determinado nos solos (Figura 4). A máxima mineralização do nitrogênio orgânico contido no lodo de curtume ocorreu em média, nos três solos, aos 70 dias após a emergência. 

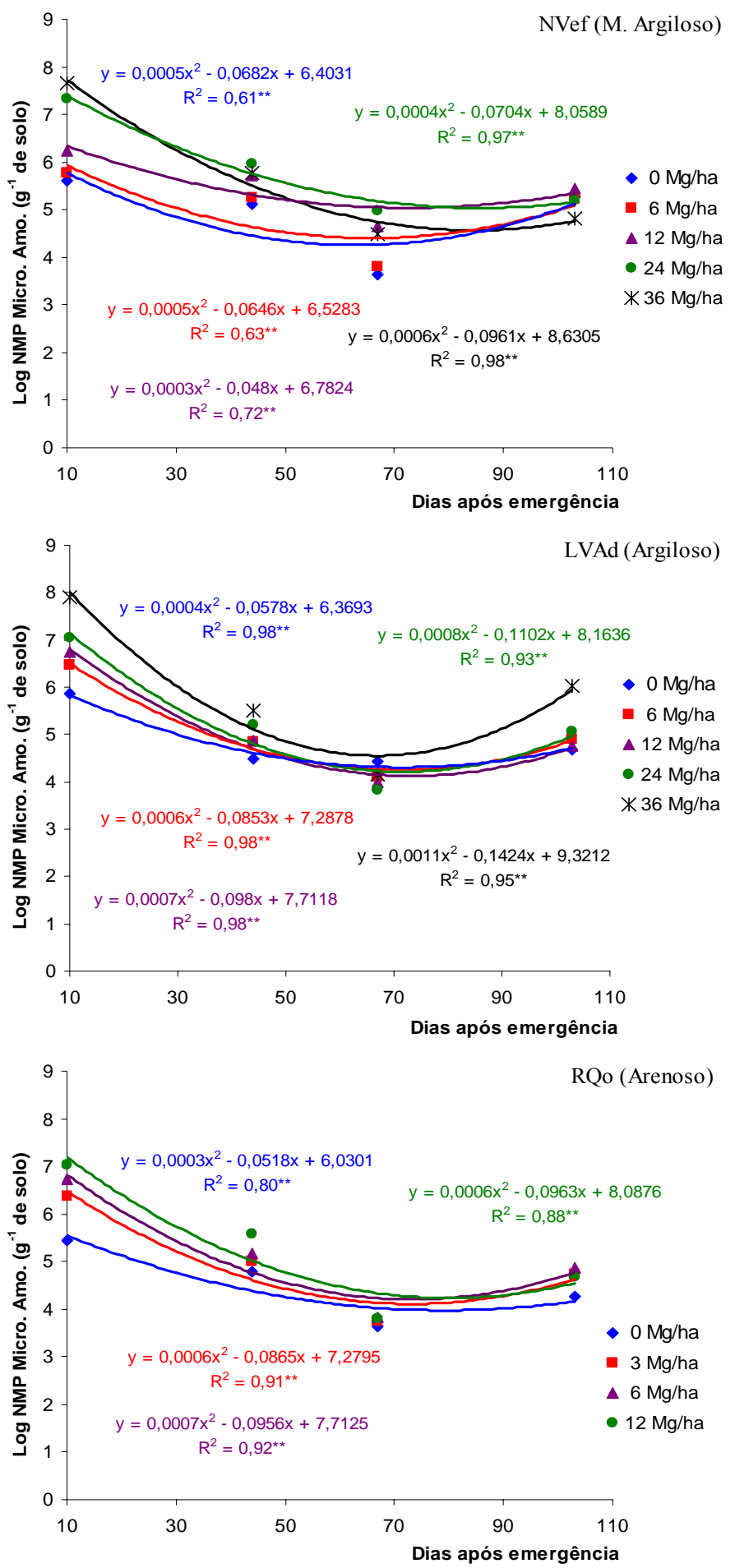

Figura 3 - Média do log do NMP de microrganismos amonificadores em três solos, tratados com doses crescentes de lodo de curtume. ${ }^{* *} \mathrm{p}<0,01$ 

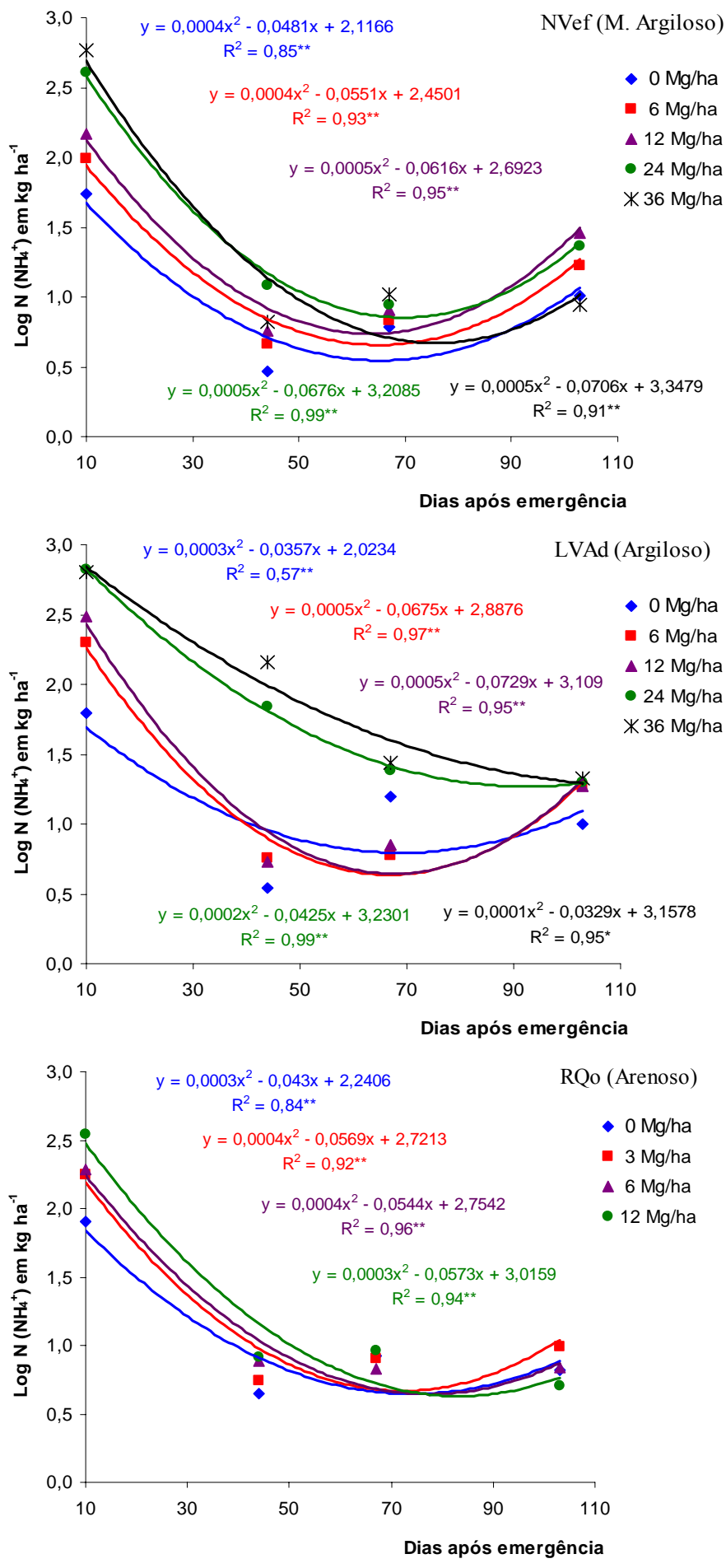

Figura 4 - Média do log de $\mathrm{N}-\mathrm{NH}_{4}{ }^{+}$em três solos, tratados com doses crescentes de lodo de curtume. $* \mathrm{p}<0,05$ e $* * \mathrm{p}<0,01$ 
Barajas-Aceves \& Dendooven (2001) demonstraram que a máxima mineralização do nitrogênio orgânico contido no lodo de curtume $\left(12,0 \mathrm{Mg} \mathrm{ha}^{-1}\right)$ ocorreu em 42 dias de incubação. A capacidade dos microrganismos amonificadores em converter $\mathrm{N}$-orgânico em $\mathrm{N}-\mathrm{NH}_{4}{ }^{+}$pode ser confirmada pela correlação positiva (Tabela 10) entre as duas variáveis.

Tabela 10. Correlação entre atributos químicos e biológicos nos três solos tratados com doses crescentes de lodo de curtume

\begin{tabular}{|c|c|c|c|c|c|c|}
\hline & $\mathrm{N}$-mineral ${ }^{1}$ & $\mathrm{~N}^{-\mathrm{NH}_{4}}{ }^{+}$ & $\mathrm{CE}^{2}$ & NMP Amo. ${ }^{3}$ & NMP Bact. ${ }^{4}$ & $\mathrm{~N}^{\circ}$ Nódulos \\
\hline \multicolumn{7}{|c|}{ NVef (M. Argiloso) } \\
\hline N-NH ${ }_{4}^{-}$ & $0,99^{* *}$ & - & - & & & \\
\hline NMP Amo. & $0,77^{* *}$ & $0,77^{* *}$ & $0,24^{*}$ & - & & \\
\hline NMP Bact. & $0,25^{*}$ & $0,25^{*}$ & $0,34^{* *}$ & $0,10^{\mathrm{NS}}$ & - & \\
\hline C-Biomassa ${ }^{5}$ & $0,44^{* *}$ & $0,45^{* *}$ & $-0,01^{\mathrm{NS}}$ & $0,72^{* *}$ & $-0,16^{\mathrm{NS}}$ & - \\
\hline $\mathrm{N}^{\mathrm{o}}$ Nódulos & $-0,41^{\mathrm{NS}}$ & $-0,24^{\mathrm{NS}}$ & $-0,68^{* *}$ & - & - & - \\
\hline MS Nódulos & $-0,30^{\mathrm{NS}}$ & $-0,29^{\mathrm{NS}}$ & $-0,58^{* *}$ & - & - & $0,88^{* *}$ \\
\hline \multicolumn{7}{|c|}{ LVAd (Argiloso) } \\
\hline $\mathrm{N}-\mathrm{NH}_{4}^{-}$ & $0,99^{* *}$ & - & - & & & \\
\hline NMP Amo. & $0,81^{* *}$ & $0,81^{* *}$ & $0,32^{*}$ & - & & \\
\hline NMP Bact. & $0,16^{\mathrm{NS}}$ & $0,16^{\mathrm{NS}}$ & $0,54^{* *}$ & $0,21^{\mathrm{NS}}$ & - & \\
\hline C-Biomassa & $0,60^{* *}$ & $0,59^{* *}$ & $0,31^{* *}$ & $0,65^{* *}$ & $-0,03^{\mathrm{NS}}$ & - \\
\hline $\mathrm{N}^{\mathrm{o}}$ Nódulos & $-0,40^{* *}$ & $-0,39^{* *}$ & $-0,48^{* *}$ & - & - & - \\
\hline MS Nódulos & $-0,35^{*}$ & $-0,35^{*}$ & $-0,53^{* *}$ & - & - & $0,94^{* *}$ \\
\hline \multicolumn{7}{|c|}{ RQo (Arenoso) } \\
\hline $\mathrm{N}-\mathrm{NH}_{4}^{-}$ & $0,99^{* *}$ & - & & & & \\
\hline NMP Amo. & $0,79^{* *}$ & $0,79^{* *}$ & $0,31^{* *}$ & - & & \\
\hline NMP Bact. & $-0,13^{\mathrm{NS}}$ & $-0,13^{\mathrm{NS}}$ & $0,20^{\mathrm{NS}}$ & $-0,11^{\mathrm{NS}}$ & - & \\
\hline C-Biomassa & $-0,35^{* *}$ & $0,35^{* *}$ & $0,22^{\mathrm{NS}}$ & $0,46^{* *}$ & $-0,40^{* *}$ & - \\
\hline $\mathrm{N}^{\circ}$ Nódulos & $-0,21^{\mathrm{NS}}$ & $-0,18^{\mathrm{NS}}$ & $-0,57^{* *}$ & - & - & - \\
\hline MS Nódulos & $-0,13^{\mathrm{NS}}$ & $-0,10^{\mathrm{NS}}$ & $-0,63^{* *}$ & - & - & $0,72^{* *}$ \\
\hline
\end{tabular}

Vários são os trabalhos indicando que o excesso de N-mineral no solo reduz a nodulação da soja, visto que, a nodulação ocorre em resposta às demandas nutricionais da 
planta (Franco et al., 1978; Scholles et al, 1983 e Paula \& Siqueira 1989). Essa redução na nodulação pode não implicar em redução no teor de $\mathrm{N}$ na planta, pois a soja tem alta capacidade em absorver simultaneamente o $\mathrm{N}$ do solo e fixar o $\mathrm{N}$-atmosférico (Scholles et al, 1983).

Foi observado um aumento no número e na matéria seca de nódulos da segunda para a terceira época de avaliação, respectivamente (Tabela 11), florescimento e enchimento de grãos, nos três solos, indicando que, no período de enchimento de grãos a demanda da planta por nitrogênio foi elevada.

Tabela 11. Matéria seca de nódulos nos três solos tratados com doses crescentes de lodo de curtume

\begin{tabular}{|c|c|c|}
\hline \multirow{2}{*}{ Dose } & \multicolumn{2}{|c|}{ Matéria Seca de Nódulos } \\
\hline & Florescimento & Enchimento de grãos \\
\hline & \multicolumn{2}{|c|}{ NVef (M. Argiloso) } \\
\hline 0 & $0,51 \mathrm{~A}$ & $2,22 \mathrm{~B}$ \\
\hline 6 & $0,53 \mathrm{~A}$ & $3,09 \mathrm{~A}$ \\
\hline 12 & $0,25 \mathrm{~B}$ & $2,32 \mathrm{~B}$ \\
\hline 24 & $0,01 \mathrm{C}$ & $1,37 \mathrm{~B}$ \\
\hline \multirow[t]{2}{*}{36} & $0,00 \mathrm{C}$ & $0,00 \mathrm{C}$ \\
\hline & \multicolumn{2}{|c|}{ LVAd (Argiloso) } \\
\hline 0 & $0,53 \mathrm{~A}$ & $2,33 \mathrm{~A}$ \\
\hline 6 & $0,31 \mathrm{AB}$ & $3,76 \mathrm{~A}$ \\
\hline 12 & $0,22 \mathrm{~B}$ & $2,94 \mathrm{~A}$ \\
\hline 24 & $0,01 \mathrm{C}$ & $0,85 \mathrm{~B}$ \\
\hline \multirow[t]{2}{*}{36} & $0,00 \mathrm{C}$ & $0,05 \mathrm{C}$ \\
\hline & \multicolumn{2}{|c|}{ RQo (Arenoso) } \\
\hline 0 & $0,47 \mathrm{~A}$ & $1,12 \mathrm{~A}$ \\
\hline 3 & $0,76 \mathrm{~A}$ & $1,77 \mathrm{~A}$ \\
\hline 6 & $0,07 \mathrm{~B}$ & $1,23 \mathrm{~A}$ \\
\hline 12 & $0,00 \mathrm{~B}$ & $0,00 \mathrm{~B}$ \\
\hline
\end{tabular}

Médias de matéria seca de nódulos, seguidas pelas mesmas letras não diferem entre si pelo teste de Tukey $(\mathrm{p}<0,05)$. 
Resultados obtidos por Franco et al. (1978) indicaram que a máxima absorção de $\mathrm{N}$-mineral ocorreu antes do florescimento, enquanto que o $\mathrm{N}$-simbiótico foi mais importante durante o período de enchimento de grãos. Segundo esses autores, mesmo no nível máximo de adubação (150 $\left.\mathrm{kg} \mathrm{ha}^{-1} \mathrm{de} \mathrm{N}\right)$ ocorreu apreciável fixação biológica de $\mathrm{N}$. A fixação biológica do N-atmosférico aparece normalmente entre 21 e 35 dias após o plantio, alcançando o máximo no início do enchimento de grãos, entrando em senescência em seguida. A demanda por nitrogênio nesse período, antes do início da fixação biológica é baixa, sendo essa demanda geralmente suprida pelo nitrogênio oriundo da semente e do solo. Esses resultados explicam a ausência de nódulos na primeira e ultima época de avaliação.

Na primeira época de avaliação (dez dias após a emergência) os teores de N$\mathrm{NH}_{4}{ }^{+}$, determinado nas amostras do NVef (M. Argiloso), LVAd (Argiloso) e RQo (Arenoso), que receberam a maior dose de lodo,corresponderam respectivamente a 491, 689 e $297 \mathrm{~kg} \mathrm{ha}^{-1}$. Teores de $\mathrm{N}$ no solo acima de $150 \mathrm{~kg} \mathrm{ha}^{-1}$ podem causar inibição da fixação biológica (Franco et al., 1978 e Paula \& Siqueira, 1989). Entretanto, para os solos NVef (M. Argiloso) e RQo (Arenoso), não foi observada correlação significativa entre $\mathrm{N}$-mineral $\left(\mathrm{NH}_{4}{ }^{+}+\mathrm{NO}_{3}{ }^{-}\right)$no solo, matéria seca de nódulos e número de nódulos. Já para o LVAd (Argiloso), essa correlação foi negativa, indicando a possível inibição da fixação biológica pelo N-mineral $\left(\mathrm{NH}_{4}{ }^{+}+\mathrm{NO}_{3}{ }^{-}\right)$contido no solo (Tabela 10).

A não correlação observada entre $\mathrm{N}$-mineral $\left(\mathrm{NH}_{4}{ }^{+}+\mathrm{NO}_{3}{ }^{-}\right)$no solo, matéria seca de nódulos e número de nódulos observada para o NVef (M. Argiloso) e RQo (Arenoso) pode estar relacionada com o baixo teor de $\mathrm{N}$-mineral $\left(\mathrm{NH}_{4}^{+}+\mathrm{NO}_{3}{ }^{-}\right)$ determinado nesses solos na época de florescimento, que foi de 14 e $9 \mathrm{~kg} \mathrm{ha}^{-1}$, respectivamente, nas maiores doses de lodo aplicadas. Para o LVAd (Argiloso), o teor de $\mathrm{N}$-mineral $\left(\mathrm{NH}_{4}{ }^{+}+\mathrm{NO}_{3}{ }^{-}\right)$determinado nessa época foi equivalente a $175 \mathrm{~kg} \mathrm{ha}^{-1}$ na maior dose de lodo aplicada, quantidade essa que poderia estar inibindo a fixação biológica do $\mathrm{N}$, como de fato ocorreu no experimento.

$\mathrm{O}$ aumento da salinidade, medida por meio da condutividade elétrica (CE), parece ter sido o fator que mais inibiu a fixação biológica do nitrogênio (Tabela11), nos três solos, visto que a correlação entre essa variável, o número de nódulos e a matéria 
seca de nódulos foi negativa em todos os solos (Tabela 10). A redução na nodulação, matéria seca de raiz e matéria seca da parte aérea pela CE também foi constatada por Mascarenhas et al. (1981). Segundo An et al. (2002), o aumento na concentração de $\mathrm{NaCl}$ no solo prejudica a absorção de água pela planta, comprometendo a traslocação de nutrientes nas plantas, principalmente para as raízes.

O NMP de microrganismos amonificadores apresentou correlação positiva com o carbono da biomassa microbiana, nos três solos estudados (Tabela 10), sugerindo que o aumento no NMP de microrganismos amonificadores contribuiu para o aumento global do carbono microbiano nos solos. Esses resultados concordam com os observados por outros autores (Jahnel, 1997; Castilhos et al., 2000 e Konrad \& Castilhos, 2001), os quais constataram aumentos significativos nas populações de bactérias, actinomicetos e fungos, após a aplicação de lodo de curtume. A amonificação é um processo que não requer a presença de microrganismos específicos (Victoria et al, 1992). Muitos microrganismos quimiorganotróficos são capazes de efetuar a transformação de Norgânico em $\mathrm{N}_{-} \mathrm{NH}_{4}{ }^{+}$. Entre os grupos de microrganismos amonificadores podemos destacar as bactérias. Entretanto, não foi observada correlação significativa entre NMP de microrganismos amonificadores e NMP de bactérias totais, nos três solos. Esses resultados podem estar relacionados a problemas metodológicos, principalmente na determinação do NMP de bactérias totais do solo. A utilização de meio de cultura não seletivo, na estimativa das densidades populacionais dos microrganismos do solo, pode mascarar os resultados (Pereira, 1996). Os meio seletivos, como o usado na determinação do NMP de microrganismos amonificadores, são os mais indicados no estudo de processos, como a mineralização do nitrogênio orgânico.

\subsubsection{Massa de matéria seca da parte aérea e produtividade de grãos}

O efeito da aplicação de doses crescentes de lodo de curtume na matéria seca da parte aérea foi quadrático e significativo nos três solos, sendo as diferenças entre os tratamentos intensificada ao longo das épocas de avaliação (Figuras 5 e 6). Os efeitos das doses de lodo de curtume aplicadas aos solos também foram verificados na produtividade de grãos, conforme pode ser visto na figura 7. 
Para o NVef (M. Argiloso), LVAd (Argiloso) e RQo (Arenoso) a produtividade máxima de grãos foi alcançada respectivamente com a doses de 17, 23 e 6 $\mathrm{Mg} \mathrm{ha}^{-1}$ de lodo de curtume, as quais representaram um ganho de produtividade de 370 , 240 e $72 \%$ em relação às testemunhas (dose 0 ). Cabe salientar, que nenhum dos tratamentos recebeu adubação para correção do $\mathrm{pH}$ (calcário), o que pode ter limitado o desenvolvimento das testemunhas (dose 0), sendo assim, o ganho de produtividade reflete o poder corretivo e fertilizante do lodo de curtume. Resultados semelhantes de também foram verificados por Costa et al. (2000) com soja, Ferreira et al. (2003) com soja e milho e Konrad \& Castilhos (2002) com milho. Esses autores também atribuíram o ganho de produtividade ao efeito corretivo e fertilizante do lodo de curtume.

Independente da dose aplicada o NVef (M. Argiloso) foi o que apresentou maior ganho de produtividade, embora não tenha tolerado doses tão altas de lodo. No LVAd (Argiloso) o ganho de produtividade foi menor, apesar da maior tolerância a altas doses de lodo. Já o RQo (Arenoso) foi o que apresentou o menor ganho de produtividade, suportando no máximo $6 \mathrm{Mg} \mathrm{ha}^{-1}$ de lodo.

As diferenças entre os valores da dose de máxima produtividade $(17,23$ e 6 $\mathrm{Mg} \mathrm{ha}^{-1}$ ), calculadas para os três solos estudados, demonstram que a fertilidade de cada solo é um dos fatores que deve ser levado em consideração na hora de decidir qual a dose de lodo a ser aplicada.

A partir das respectivas doses de máxima produtividade foram observados decréscimos na produtividade de matéria seca e de grãos nas plantas, nos três solos estudados, sendo esse efeito mais acentuado no NVef (M. Argiloso) chegando até ao definhamento das plantas na dose de $36 \mathrm{Mg} \mathrm{ha}^{-1}$ e no RQo (Arenoso), causando a morte das plantas na dose de $24 \mathrm{Mg} \mathrm{ha}^{-1}$ (Figura 6). A limitação na produtividade pode estar associada ao efeito aditivo do aumento na $\mathrm{CE}$, teor de sódio trocável no solo e $\mathrm{pH}$, os quais alteraram de forma diferenciada a fertilidade de cada solo. 

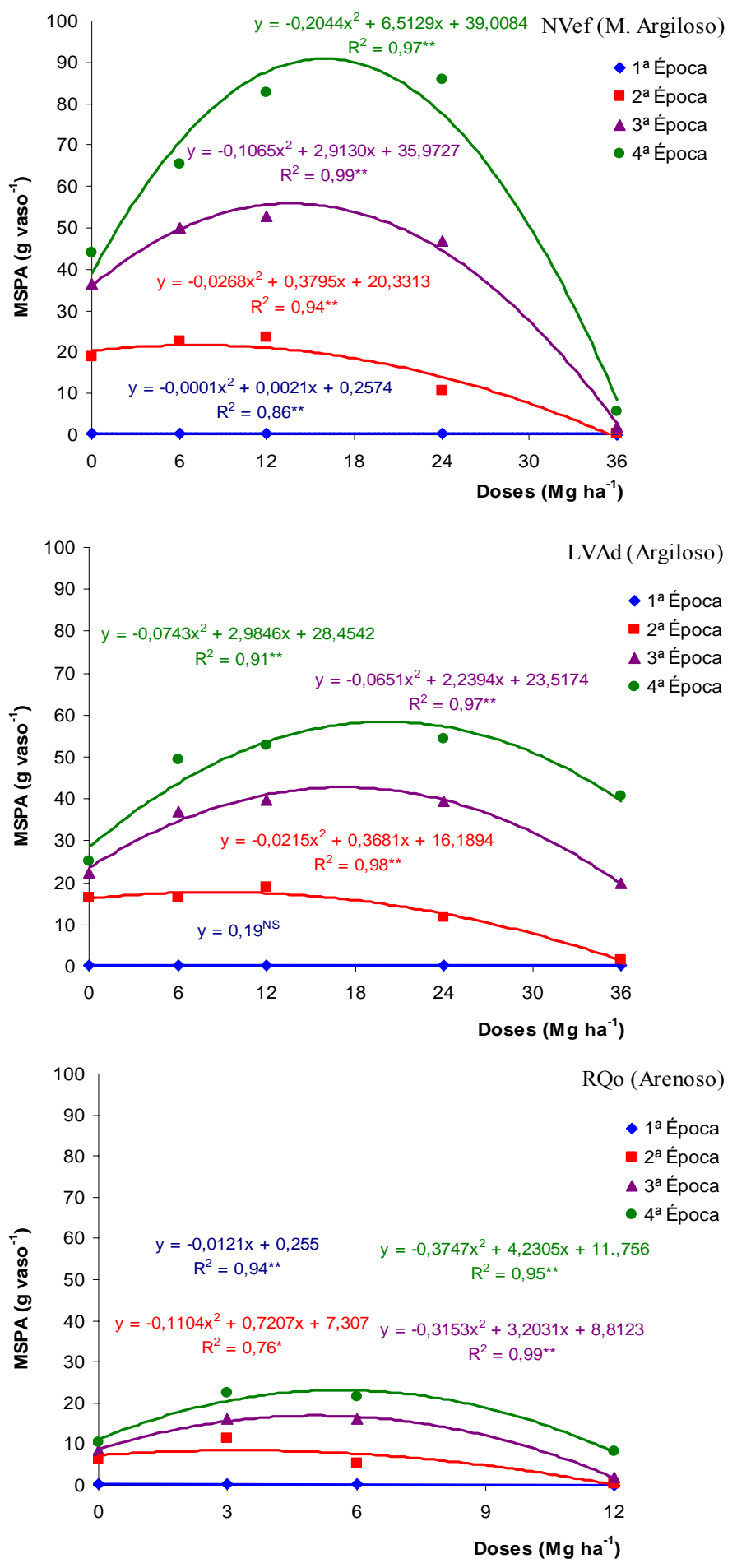

Figura 5 - Rendimento médio de matéria seca da parte aérea em quatro épocas de avaliação ( $1^{\mathrm{a}}$ folha, florescimento, enchimento de grãos e maturação) em três solos, tratados com doses crescentes de lodo de curtume. ${ }^{N S} \mathrm{p}>0,05,{ }^{*} \mathrm{p}<0,05$ e ${ }^{* *} \mathrm{p}<0,01$ 

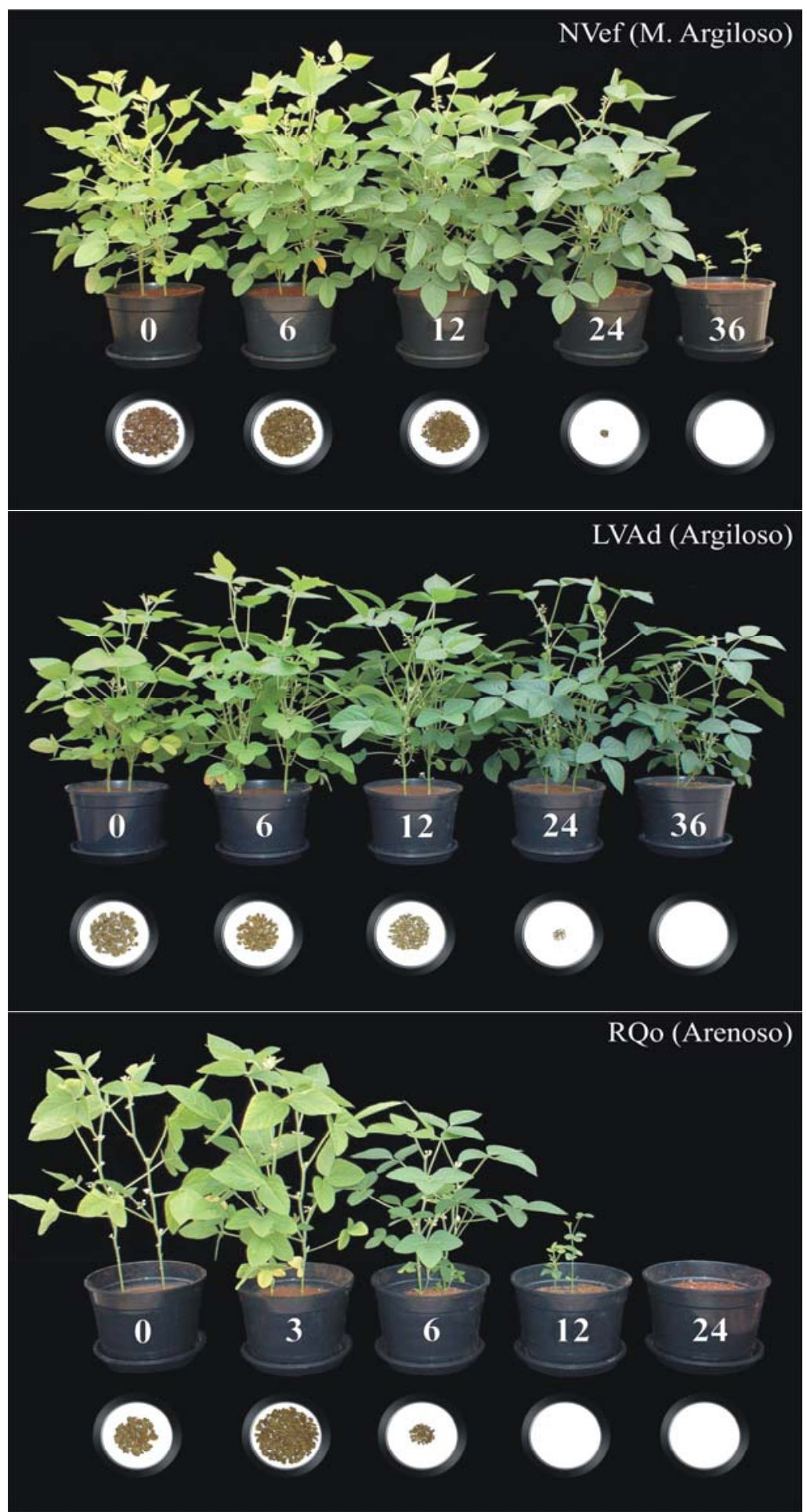

Figura 6 - Efeito da aplicação de lodo de curtume no desenvolvimento das plantas de soja e na matéria seca de nódulos na época de florescimento, em três solos. Os números encontrados nos vasos correspondem às doses de lodo aplicadas em $\mathrm{Mg} \mathrm{ha}^{-1}$ 


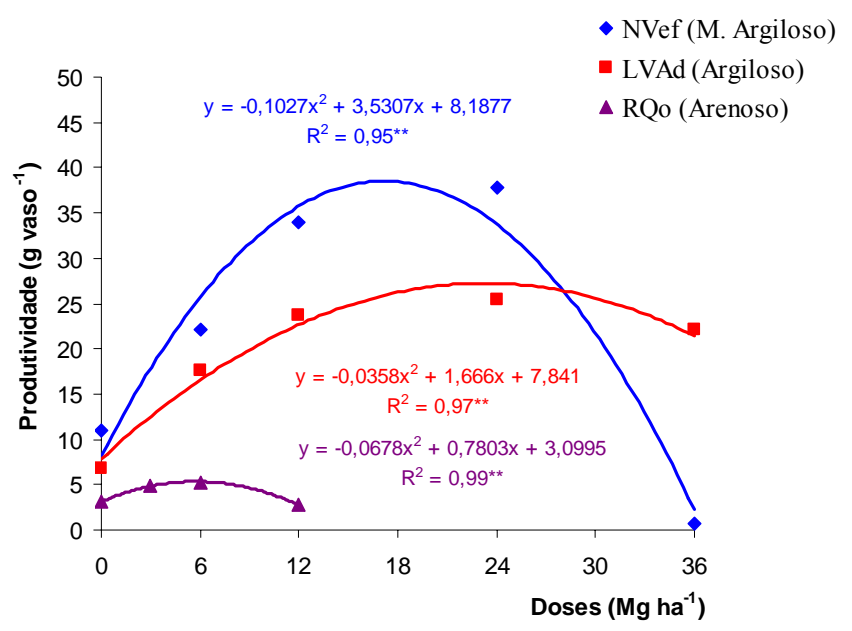

Figura 7 - Produtividade média de grãos em três solos tratados com doses crescentes de lodo de curtume. ${ }^{*} \mathrm{p}<0,05$ e ${ }^{* *} \mathrm{p}<0,01$

\subsubsection{Condutividade elétrica (CE), sódio trocável e pH dos solos}

Os valores de sódio trocável no solo e a $\mathrm{CE}$ aumentaram com o aumento das doses de lodo de curtume, nos três solos estudados (Figuras 8 e 9).

Para o NVef (M. Argiloso) e RQo (Arenoso), esses aumentos influenciaram de forma negativa a matéria seca da parte aérea, conforme revelado pela análise de correlação (Tabela 12). Entretanto, esse efeito não ficou muito evidente no LVAd (Argiloso), que apresentou baixa correlação negativa com a CE e não significativa com o teor de sódio trocável no solo. Sendo constatado correlação positiva entre a produtividade de grãos e a CE e teor de sódio trocável (PST), indicando um possível efeito benéfico do aumento de sódio nesse solo. O LVAd (Argiloso) também foi o solo que apresentou o maior teor de sódio trocável (até $30 \mathrm{mmol}_{\mathrm{c}} \mathrm{kg}^{-1}$ ) na doses de máxima produtividade (24 $\mathrm{Mg} \mathrm{ha}^{-1}$ ), em relação ao NVef (M. Argiloso), até $25 \mathrm{mmol}_{\mathrm{c}} \mathrm{kg}^{-1} \mathrm{na}$ dose de $17 \mathrm{Mg} \mathrm{ha}^{-1}$ e RQo (Arenoso), até $7 \mathrm{mmol}_{\mathrm{c}} \mathrm{kg}^{-1}$ na dose de $6 \mathrm{Mg} \mathrm{ha}^{-1}$. 

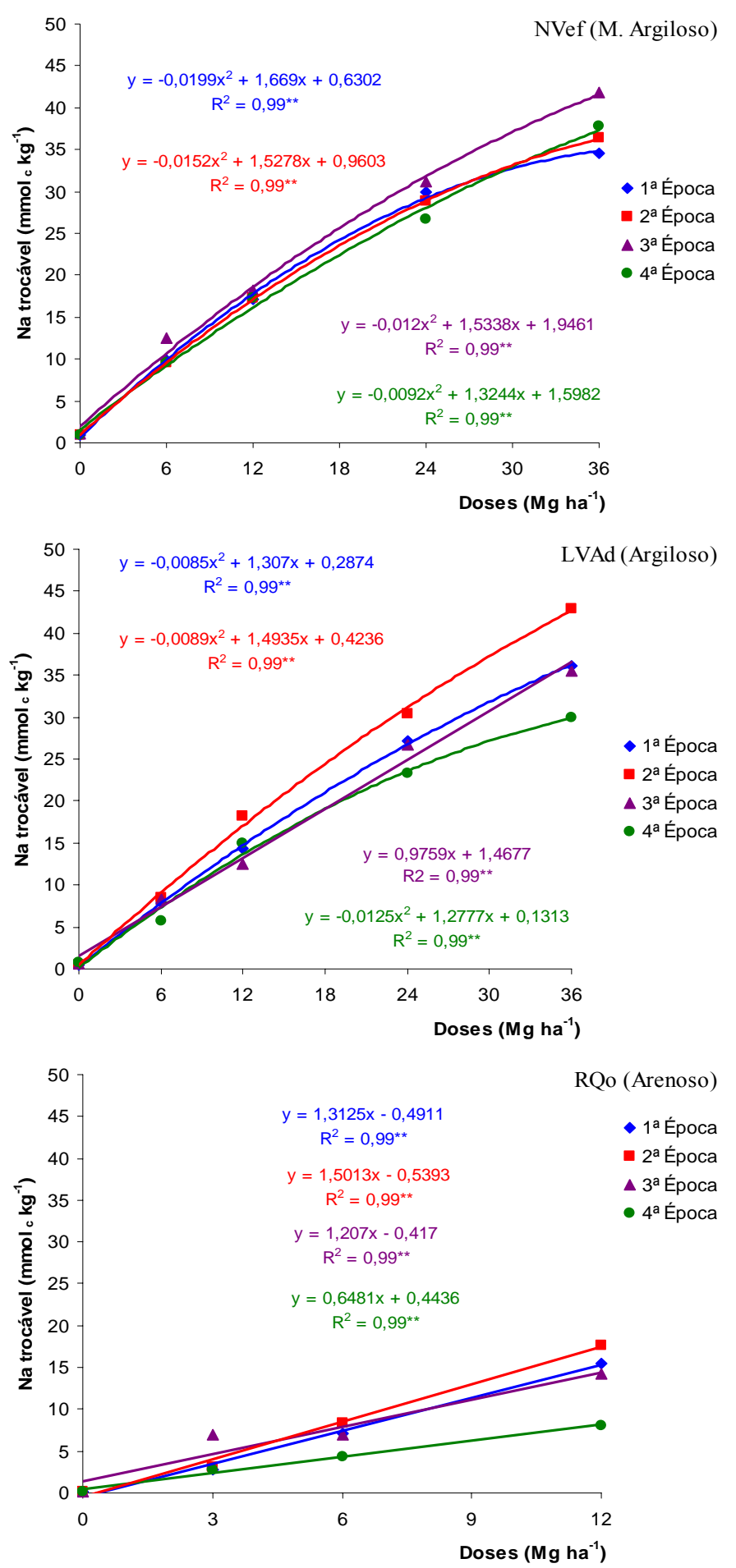

Figura 8 - Sódio trocável médio em quatro épocas de avaliação (10, 44, 67 e 103 dias após emergência) em três solos, tratados com doses crescentes de lodo de curtume. p** $<0,01$ 

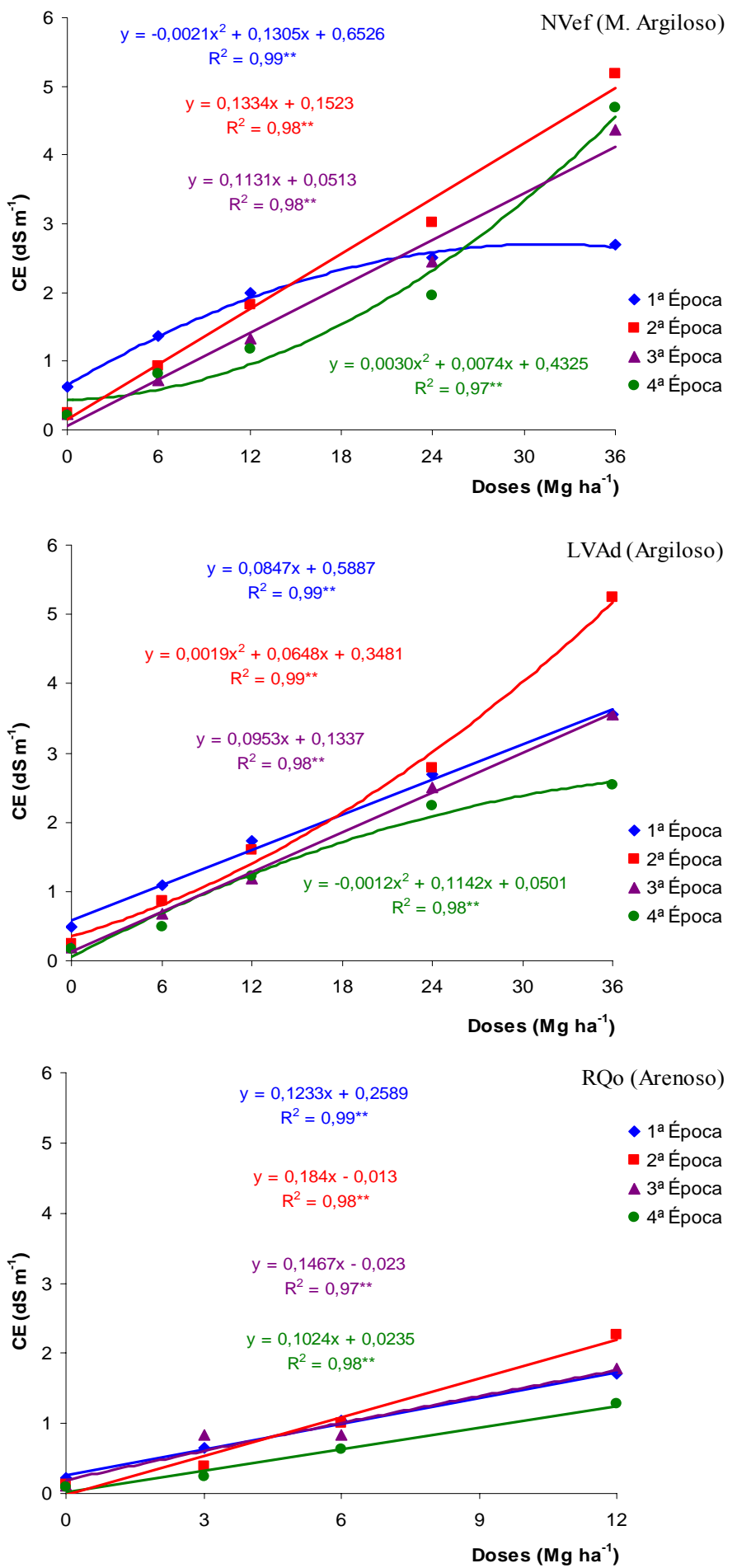

Figura 9 - CE média em quatro épocas de avaliação (10, 44, 67 e 103 dias após emergência) em três solos, tratados com doses crescentes de lodo de curtume. ${ }^{* *} \mathrm{p}<0,01$ 
Tabela 12. Correlação entre produtividade de grãos, matéria seca da parte aérea, sódio acumulado na planta e atributos químicos nos três solos tratados com doses crescentes de lodo de curtume

\begin{tabular}{|c|c|c|c|c|c|}
\hline & $\begin{array}{c}\text { Produtividade de } \\
\text { grãos }\end{array}$ & $\mathrm{MSPA}^{\mathrm{a}}$ & $\begin{array}{c}\mathrm{Na} \text { acumulado na } \\
\text { planta }\end{array}$ & $\mathrm{CE}^{\mathrm{b}}$ & $\begin{array}{l}\text { Na trocável no } \\
\text { solo }\end{array}$ \\
\hline \multicolumn{6}{|c|}{ NVef (M. Argiloso) } \\
\hline MSPA & $0,97^{* *}$ & - & & & \\
\hline $\mathrm{Na}$ acumulado na planta & - & $-0,60^{* *}$ & & & \\
\hline $\mathrm{CE}$ & $-0,44^{*}$ & $-0,43^{* *}$ & $0,79^{* *}$ & - & \\
\hline Na trocável no solo & $-0,11^{\mathrm{NS}}$ & $-0,24^{*}$ & $0,83^{* *}$ & $0,90^{* *}$ & - \\
\hline $\mathrm{PST}^{\mathrm{c}}$ & $0,02^{\mathrm{NS}}$ & $-0,08^{\mathrm{NS}}$ & $0,84^{* *}$ & $0,80^{* *}$ & $0,96^{* *}$ \\
\hline \multicolumn{6}{|c|}{ LVAd (Argiloso) } \\
\hline MSPA & $0,94^{* *}$ & - & & & \\
\hline $\mathrm{Na}$ acumulado na planta & - & $0,05^{\mathrm{NS}}$ & & & \\
\hline $\mathrm{CE}$ & $0,59^{* *}$ & $-0,25^{*}$ & $0,25^{\mathrm{NS}}$ & - & \\
\hline Na trocável no solo & $0,60^{* *}$ & $-0,12^{\mathrm{NS}}$ & $0,44^{*}$ & $0,97^{* *}$ & - \\
\hline PST & $0,63^{* *}$ & $-0,15^{\mathrm{NS}}$ & $0,74^{* *}$ & $0,86^{* *}$ & $0,91^{* *}$ \\
\hline \multicolumn{6}{|c|}{ RQo (Arenoso) } \\
\hline MSPA & $0,95^{* *}$ & - & & & \\
\hline $\mathrm{Na}$ acumulado na planta & - & $-0,68^{* *}$ & - & & \\
\hline $\mathrm{CE}$ & $-0,31^{\mathrm{NS}}$ & $-0,47^{* *}$ & $0,96^{* *}$ & - & \\
\hline Na trocável no solo & $-0,16^{\mathrm{NS}}$ & $-0,40^{* *}$ & $0,96^{* *}$ & $0,96^{* *}$ & - \\
\hline PST & $0,02^{\mathrm{NS}}$ & $-0,32^{*}$ & $0,96^{* *}$ & $0,80^{* *}$ & $0,83^{* *}$ \\
\hline
\end{tabular}

${ }^{\mathrm{a}}$ Matéria seca da parte aérea; ${ }^{\mathrm{b}}$ Condutividade elétrica;

${ }^{\mathrm{c}}$ Porcentual de sódio trocável no solo $[\mathrm{Na} /(\mathrm{Ca}+\mathrm{Mg}+\mathrm{K}+\mathrm{Na}+\mathrm{H}+\mathrm{Al}) \times 100]$;

${ }^{\mathrm{NS}} \mathrm{p}>0,05, * \mathrm{p}<0,05$ e $* * \mathrm{p}<0,01$.

A maior capacidade do LVAd (Argiloso) em suportar elevadas doses de lodo de curtume pode estar relacionada com a maior necessidade de correção desse solo, o qual apresentava inicialmente $\mathrm{pH} \mathrm{3,9}$, saturação por bases de 5,2\% e CTC de $120 \mathrm{mmol}_{\mathrm{c}}$ $\mathrm{kg}^{-1}$ (Tabela 3). Além disso, esse solo foi o que apresentou o maior teor de carbono orgânico (Tabela 3), o qual também pode estar contribuindo para esses resultados.

A capacidade de troca catiônica (CTC) também é um fator importante no controle do aumento da CE, uma vez que solos com CTC mais elevada tendem a apresentar menores 
valores de CE. Abreu Junior et al. (2000), ao estudarem o efeito da aplicação de composto de lixo, com elevados teores de sais, em solos de diferentes regiões do Brasil, constataram que solos com CTC superior a $80 \mathrm{mmol}_{\mathrm{c}} \mathrm{kg}^{-1}$ apresentaram os menores valores de CE. Segundo esses autores, a CTC inicial dos solos é uma das propriedades mais importantes no controle do aumento da CE, visto que ela não reflete apenas o teor de argila e matéria orgânica, mas também o tipo de argila.

O efeito das doses de lodo de curtume sobre os valores de CE, conforme revelado pela análise de correlação (Tabela 12), foi conseqüência do aumento no teor de Na trocável no solo, o qual também contribuiu para o aumento no porcentual de sódio trocável (PST). Esse comportamento também foi observado por outros autores (Konrad \& Castilhos, 2002 e Aquino Neto \& Camargo, 2000). De acordo com a Figura 9, os maiores valores de CE ocorreram nos solos que receberam as maiores doses de lodo, chegando a $5 \mathrm{dS} \mathrm{m}^{-1}$ no NVef (M. Argiloso) e LVAd (Argiloso) e $2 \mathrm{dS} \mathrm{m}^{-1}$ no RQo (Arenoso). Segundo Richards (1954), valores de CE superiores a $4 \mathrm{dS} \mathrm{m}^{-1}$ classificam o solo como salino, podendo ocasionar decréscimos na permeabilidade e acentuar o problema de concentração de sais.

As maiores doses de lodo de curtume utilizadas nos experimentos adicionaram quantidades de $\mathrm{Na}$ equivalente 2156,8 $\mathrm{kg} \mathrm{ha}^{-1}$ ao NVef (M. Argiloso), LVAd (Argiloso) e $1437,9 \mathrm{~kg} \mathrm{ha}^{-1}$ ao RQo (Arenoso). Segundo norma P4.233 da CETESB (1999), o limite máximo de aplicação anual de $\mathrm{Na}$ em solos muito argilosos e argilosos é de $1000 \mathrm{~kg} \mathrm{ha}^{-1}$, já para solos arenosos esse limite é de $400 \mathrm{~kg} \mathrm{ha}^{-1}$. Entretanto, considerando-se as doses de produtividade máxima calculadas para os três solos, apenas o NVef (M. Argiloso) (16 $\left.\mathrm{Mg} \mathrm{ha}^{-1}\right)$ e o LVAd (Argiloso) (24 $\left.\mathrm{Mg} \mathrm{ha}^{-1}\right)$ adicionaram quantidades de sódio, superiores respectivamente, em $4 \mathrm{e}$ 44\% o limite máximo permitido pela CETSB. Para o LVAd (Argiloso), a adição de 44\% a mais que o limite permitido pela CETESB parece não ter prejudicado a produtividade de grãos, visto que a correlação entre essa variável e CE, sódio trocável no solo e PST foram positivas.

Aquino Neto \& Camargo (2000) ao estudarem os crescimento de plantas de alface cultivadas em solo arenoso que recebeu $30 \mathrm{Mg} \mathrm{ha}^{-1}$ de lodo de caleiro, verificaram um decréscimo acentuado na produção de matéria seca da alface nos tratamento que apresentavam CE no solo igual ou superior a $1,7 \mathrm{dS} \mathrm{m}^{-1}$. Essa (2002), ao estudar o efeito do estresse salino em cultivares de soja, constatou que valores de CE superior a 2,5 $\mathrm{dS} \mathrm{m}^{-1}$ nos solos reduziram a 
germinação das sementes de soja e o peso da matéria seca da parte aérea. Segundo o autor, as cultivares de soja apresentaram níveis diferenciados de tolerância ao estresse salino, sendo esse comportamento atribuído às características genéticas de cada cultivar.

Verificou-se que as altas concentração de sódio trocável no solo apresentaram correlação significativa com o teor de sódio acumulado na planta de soja (Tabela 12), indicando que as plantas de soja foram capazes de absorver o sódio disponível na solução do solo. Segundo Ayers \& Westcot, (1985), a soja é considerada uma planta tolerante ao sal, podendo suportar valores de $\mathrm{CE}$ superiores a $5 \mathrm{dS} \mathrm{m}^{-1}$ (extrato de saturação). Essa tolerância deve-se principalmente à capacidade das plantas em translocar $\mathrm{Na}$ e $\mathrm{Cl}$ por meio do floema e, dessa forma, diluir os sais por toda a planta (An et al., 2002). Entretanto, altas concentrações de Na e, sobretudo, excesso de $\mathrm{Cl}$ no protoplasma das plantas ocasionam distúrbios no balanço iônico do $\mathrm{K}$ e Ca, afetando principalmente a taxa de crescimento e a produção de matéria seca da planta (Larcher, 2000).

Os valores de $\mathrm{pH}$ nos três solos estudados variaram em função da dose de lodo de curtume aplicada, sendo seu efeito prolongado até a ultima época de avaliação (Figura 10). Em média, no NVef (M. Argiloso) e RQo (Arenoso) o pH aumentou de 4,5 para 7,0. Já o LVAd (Argiloso) apresentou aumento no $\mathrm{pH}$ de 4,0 para 6,0. O efeito corretivo do lodo de curtume também foi observado por outros autores (Jahnel, 1997; Konrad \& Castilhos, 2002; Selbach et al., 1991), sendo atribuído à alcalinidade do lodo, decorrente dos altos teores de carbonato e hidróxido de cálcio e magnésio presentes no resíduo.

$\mathrm{O}$ aumento no $\mathrm{pH}$, observado principalmente no NVef (M. Argiloso) e RQo (Arenoso) quando receberam as maiores doses de lodo de curtume, também podem ter contribuído para o decréscimo na produtividade de matéria seca da parte aérea e produtividade de grãos. Valores de $\mathrm{pH}$ superiores a seis podem causar desequilíbrio na fertilidade química do solo, principalmente reduzindo o teor disponível de micronutrientes para as plantas (Quaggio et al., 1982). 

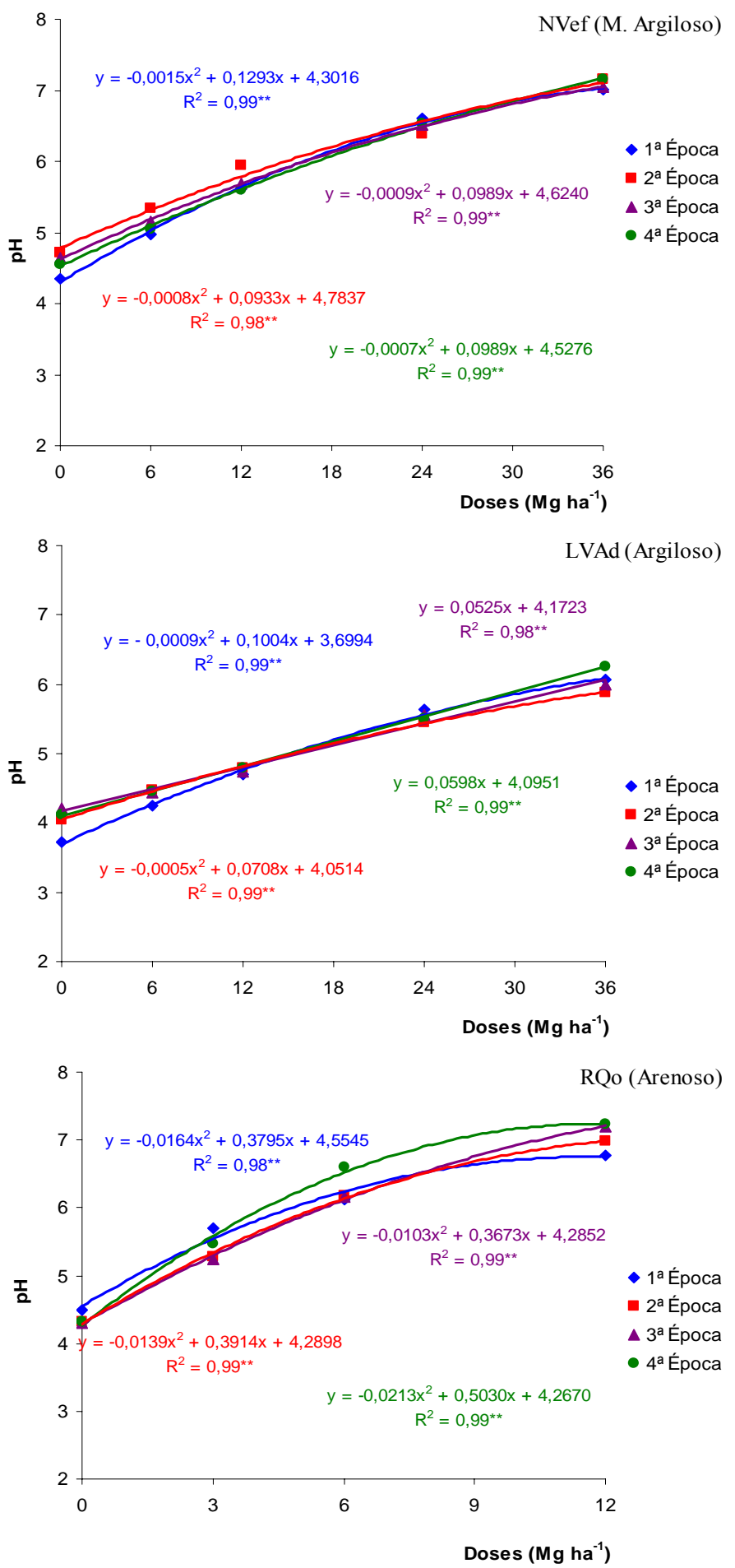

Figura 10 - Valor médio de pH em quatro épocas de avaliação (10, 44, 67 e 103 dias após emergência) em três solos, tratados com doses crescentes de lodo de curtume. *** $<0,01$ 


\subsection{Apreciação geral dos resultados obtidos}

O lodo de curtume oriundo da mistura do lodo do caleiro com o lodo primário da ETE pode ser reciclado em solos agrícolas. O cálculo da dose a ser aplicada deve levar em consideração as características do solo (sobretudo CTC e pH), teor de sódio e crômio contidos no lodo de curtume.

As culturas a serem utilizadas nas áreas que receberão o lodo de curtume devem ser, preferencialmente, tolerantes a sódio e exigentes em nitrogênio.

A utilização de metodologias como a da respirometria e do número mais provável de microrganismos amonificadores mostraram ser adequadas ao estudo da degradação do carbono e mineralização do nitrogênio contido no lodo de curtume.

A separação dos resíduos gerados durante o processamento das peles é primordial na redução de elementos potencialmente poluidores como o crômio e o sódio. Segundo a CETESB (1999) o deságüe do lodo de curtume, por meio de prensagem, centrifugação ou drenagem, pode reduzir o teor de sódio encontrado no lodo de curtume, o que seria fundamental para permitir a aplicação de doses mais elevadas sem causar prejuízos às plantas e ao meio ambiente.

Estudos a campo com doses crescentes de lodo de curtume devem ser conduzidos a fim de avaliar a dinâmica do nitrogênio e do sódio no solo. 


\section{CONCLUSÕES}

1. A atividade microbiana, medida por meio do $\mathrm{C}_{-}-\mathrm{CO}_{2}$, aumenta com o aumento da dose de lodo de curtume aplicada nos solos, não sendo observado efeito inibitório.

2. A taxa de degradação da fração orgânica do lodo de curtume varia em função do solo e da dose de lodo aplicada, sendo $58 \%$ a menor taxa de degradação ao final do período de avaliação e $101 \%$ a maior.

3. O modelo de cinética química de primeira ordem ajusta-se adequadamente aos dados de $\mathrm{C}-\mathrm{CO}_{2}$.

4. A mineralização do nitrogênio orgânico do lodo de curtume varia em função do solo e da dose de lodo aplicada, sendo observados os mais altos teores de $\mathrm{N}$ mineral $\left(\mathrm{NH}_{4}{ }^{+}+\mathrm{NO}_{3}{ }^{-}\right)$nos solos, na primeira época de avaliação, 24 dias após a aplicação do lodo.

5. As doses de 17, 23 e $6 \mathrm{Mg} \mathrm{ha}^{-1}$, respectivamente para o NVef (M. Argiloso), LVAd (Argiloso) e RQo (Arenoso), proporcionaram ganhos de produtividade de grãos de 370, 240 e 72\% em relação aos tratamentos que não receberam lodo de curtume (dose 0). Tal efeito pode ser atribuído ao poder corretivo e fertilizante do lodo de curtume.

6. O lodo de curtume pode ser utilizado como corretivo da acidez do solo.

7. Aumentos na $\mathrm{CE}$ e no teor de sódio trocável que ocorrem nos solos com altas doses de lodo de curtume, podem proporcionar impacto negativo no desenvolvimento da soja e até impedir o desenvolvimento da planta. 


\section{REFERÊNCIAS BIBLIOGRÁFICAS}

ABREU JUNIOR, C.H.; MURAOKA, T.; LAVORANTE, A.F.; ALVAREZ, F.C.V. Condutividade elétrica, reação do solo e acidez potencial em solos adubados com composto de lixo. Revista Brasileira de Ciência do Solo, v.24, p.635-647, 2000.

ABREU, M.F.; ABREU, C.A.; ANDRADE, J.C. Determinação de fósforo, potássio, cálcio, magnésio, enxofre, cobre, ferro, manganês, zinco, níquel, cádmio, cromo e chumbo em ácido nítrico usando métodos da US-EPA. In: RAIJ, B.van.; ANDRADE, J.C.; CANTARELlA, H.; QUAGGIO, J.A. (Ed.). Análise química para avaliação da fertilidade de solos tropicais. Campinas: Instituto Agronômico, 2001.cap.17, p.251-261.

ALCÂNTARA, M.A.K.; CAMARGO, O.A. Transporte de crômio trivalente influenciado pelo $\mathrm{pH}$, horizonte do solo e fontes do crômio. Revista Brasileira de Engenharia Agrícola e Ambiental, v.5, n.3, p.493-501, 2001.

ALVES, B.J.F.; SANTOS, J.C.F.; URQUIAGA, S.; BODDEY, R. Métodos de determinação do nitrogênio em solo e planta. In: HUNGRIA, M.; ARAUJO, R.S. (Ed.). Manual de métodos empregados em estudos de microbiologia agrícola. Brasília: EMBRAPA, 1994. cap.23, p.449-471.

AN, P.; INANAGA, S.; COHEN, Y.; KAFKAFI, U.; SUGIMOTO, Y. Salt tolerance in two soyben cultivars. Journal of Plant Nutrition, v.25, n.3, p.407-423, 2002.

ANDERSON, J.P.E. Soil respiration. In: PAGE, A.L.; MILLER, R.H.; KEENEY, D.R. (Ed.). Methods of soil analysis. 2.ed. Madison: American Society of Agronomy, 1982. pt. 2: Chemical and microbiological properties, cap.41, p.831-872. (Agronomy. A Series of Monographs, 9) 
ANDRADE, C.A. Fração orgânica de biossólidos e efeito no estoque de carbono e qualidade da matéria orgânica de um latossolo cultivado com eucalipto. Piracicaba, 2004. 121p. Tese (Doutorado) - Escola Superior de Agricultura "Luiz de Queiroz", Universidade de São Paulo.

ANDRADE, D.S.; MIYAZAWA, M.; HAMAKAWA, P.J. Microrganismos amonificadores e nitrificadores. In: HUNGRIA, M.; ARAUJO, R.S. (Ed.). Manual de métodos empregados em estudos de microbiologia agrícola. Brasília: EMBRAPA, 1994. cap.17, p.356-376.

AQUINO NETO, V. Avaliação do aproveitamento agrícola de lodos de curtume. Piracicaba, 1998. 111p. Dissertação (Mestrado) - Escola Superior de Agricultura "Luiz de Queiroz", Universidade de São Paulo.

AQUINO NETO, V.; CAMARGO, O.A. Crescimento e acúmulo de crômio em alface cultivada em dois latossolos tratados com $\mathrm{CrCl}_{3}$ e resíduos de curtume. Revista Brasileira de Ciência do Solo, v.24, p.225-235, 2000.

AYERS, R.S.; WESTCOT, D.S. Water quality for agriculture. Rome: FAO, 1985. 174p. (Irrigation and Drainage Paper, 29).

BARAJAS-ACEVES, M.; DENDOOVEN, L. Nitrogen, carbon and phosphorus mineralization in soils from semi-arid highlands of central Mexico amended with tannery sludge. Bioresource Technology, v.77, n.2, p.121-130, 2001.

BARROS, M.A.S.D.; ARROYO, P.A.; SOUSA-AGUIAR, E.F.; SEGARRA, V. O processamento de peles. In: BARROS, M.A.S.D.; ARROYO, P.A.; SOUSAAGUIAR, E.F.; GARCIA, P.A. (Ed.). Problemas ambientais com soluções cataliticas: I. o cromo no processamento de peles Madrid: Ciencia y Tecnologia para el Desarrollo, 2001. cap.4, p.37-63.

BARTLETT, R.J.; JAMES, B.R. Mobility and bioavailability of chromium in soils. In: NRIAGU, J.O.; NIEBOER, E. (Ed.). Chromium in the natural and human environments. New York: John Wiley, 1988. cap.10, p.267-308. (Advances in Environmental Science and Technology, 20) 
BARTLETT, R.J.; KIMBLE, J.M. Behavior of chromium in soil: I trivalent forms. Journal of Environmental Quality, v.5, n.4, p.379-382, 1976.

BERNAL, M.P.; SÁNCHEZ-MONEDERO, M.A.; PAREDES, C.; ROIG, A. Carbon mineralization from organic wastes at different composting stages during their incubation with soil. Agriculture, Ecosystems and Environment, v.69, p.175-189, 1998.

BOHNEN, H.; MEURER, E.J.; BISSANI, C.A. Solos ácidos e solos afetados por sais. In: MEURER, E.J. (Ed.). Fundamentos de química do solo. Porto Alegre: Genesis, 2000. cap.6, p.109-125.

BRASIL. Lei n 6.938 de 31 de agosto de 1981. Diário Oficial, 31 ago. 1981. Dispõe sobre a política nacional do meio ambiente, seus fins e mecanismos de formulação e aplicação, e dá outras providências.

BROOKES, P.C. The use of microbial parameters in soil pollution by heavy metals. Biology and Fertility of Soils, v.19, n.4, p.269-279, 1995.

CAMARGO, O.A.; MONIZ, A.C.; JORGE, J.A.; VALADARES, J.M.A.S. Métodos de análise química, mineralógica e física de solos do Instituto Agronômico de Campinas. Campinas: Instituto Agronômico, 1986. 94p. (Boletim Técnico, 106)

CASTILHOS, D.D.; VIDOR, C.; CASTILHOS, R.M.V. Atividade microbiana em solo suprido com lodo de curtume e cromo hexavalente. Revista Brasileira de Agrociência, v.6, n.1, p.71-76, 2000.

CASTILHOS, D.D.; VIDOR, C.; TEDESCO, M.J. Redução do Cromo em solo suprido com lodo de curtume e cromo hexavalente. Revista Brasileira de Agrociência, v.5, n.3, p.228-232, 1999.

CHAE, Y.M.; TABATABAI, M.A. Mineralization of nitrogen in soils amended with organic wastes. Journal of Environmental Quality, v.15, p.193-198, 1986.

CLAAS, I.C.; MAIA, R.A.M. Manual básico de resíduos industriais de curtume. Porto Alegre: SENAI Rio Grande do Sul 1994. 664p.

COMPANHIA DE TECNOLOGIA DE SANEAMENTO AMBIENTAL. Lodo de curtume: critérios para o uso em áreas agrícolas e procedimentos para apresentação de projetos (Manual Técnico). São Paulo, 1999. 35p. 
COSTA, C.N.; CASTILHOS, D.D.; CASTILHOS, R.M.V.; KONRAD, E.E.; PASSIANOTO, C.C.; RODRIGUES, C.G. Efeito da adição de lodos de curtume sobre as alterações químicas do solo, rendimento de matéria seca e absorção de nutrientes em soja. Revista Brasileira de Agrociência, v.7, n.3, p.189-1, 2000.

DOMSCH, K.H.; JAGNOW, G.; ANDERSON, T.H. An ecological concept for the assessment of side effects of agrochemicals on soil microorganisms. Residue Reviews, v.86, p.65-105, 1983.

EMPRESA BRASILEIRA DE PESQUISA AGROPECUÁRIA. Manual de análises químicas de solos, plantas e fertilizantes. Brasília: EMBRAPA Comunicação para Transferência de Tecnologia, 1999a. 370p.

EMPRESA BRASILEIRA DE PESQUISA AGROPECUÁRIA. Sistema brasileiro de classificação de solos. Brasília: EMBRAPA Produção de Informações, 1999b. $412 p$.

ESSA, T.A. Effect of salinity stress on growth and nutrient composition of three soybean (Glycine max L. Merrill) cultivars. Journal Agronomy \& Crop Science, v.188, p.86-93, 2002.

FEHR, W.R.; CAVINES, C.E.; BURMOOD, D.T.; PENNINGTON, J.S. Stage of development descriptons for soybeans, Glycine max (L.) Merrill. Crop Science, v.11, p.929-931, 1971.

FEIGIN, A.; RAVINA, I.; SHALHEVET, J. Irrigation with treated sewage effluent: management for environmental protection. Berlin: Springer-Verlag, 1991. 224p.

FERREIRA, A.S.; CAMARGO, F.A.O.; TEDESCO, M.J.; BISSANI, C.A. Alterações de atributos químicos e biológicos de solo e rendimento de milho e soja pela utilização de resíduos de curtume e carbonífero. Revista Brasileira de Ciência do Solo, v.27, p.755-763, 2003.

FIGliOliA, A.; BENEDETTI, A.; DELl'ABATE, M.T.; IZZA, C.; INDIATI, R. Potential chromium bio-availability by Lactuca sativa grown on two soils amended with tannery leather residues. Fresenius Environmental Bulletin, v.1, p.406-410, 1992. 
FRANCO, A.A.; FONSECA, O.O.M.; MARRIEL, I.E. Efeito do nitrogênio mineral na na atividade da nitrogenase e nitrato redutase, durante o ciclo da soja no campo. Revista Brasileira de Ciência do Solo, v.2, p.110-114, 1978.

INSTITUTO BRASILEIRO DE GEOGRAFIA E ESTATÍSTICA. Produção da pecuária municipal 2003. Rio de Janeiro, 2003. v.31, 31p.

IRVINE, S.A.; REID, D.J. Field prediction of sodicity in dryland agriculture in Central Queensland, Australia. Australian Journal of Soil Research, v.39, p.1349-1357, 2001 .

JAHNEL, M.C. Método de plaqueamento por gotas e outros parâmetros microbiológicos na avaliação da decomposição de lodo ativado de curtume em solos. Piracicaba, 1997. 79p. Tese (Doutorado) - Escola Superior de Agricultura "Luiz de Queiroz", Universidade de São Paulo.

JAHNEL, M.C.; CARDOSO, E.J.B.N.; DIAS, C.T.S. Determinação do número mais provável de microrganismos do solo pelo método de plaqueamento por gotas. Revista Brasileira de Ciência do Solo, v.23, p.553-559, 1999.

KIEHL, E.J. Fertilizantes orgânicos. São Paulo: Agronômica Ceres, 1985. 492p.

KONRAD, E.E.; CASTILHOS, D.D. Atividade microbiana em um planossolo após a adição de resíduos de curtume. Revista Brasileira de Agrociência, v.7, n.2, p.131$135,2001$.

KONRAD, E.E.; CASTILHOS, D.D. Alterações químicas do solo e crescimento do milho decorrente da adição do lodo de curtume. Revista Brasileira de Ciência do Solo, v.26, p.257-265, 2002.

KUZYAKOV, Y.; FRIEDEL, J.K.; STAHR, K. Review of mechanisms and quantification of priming effects. Soil Biology and Biochemistry, v.32, p.1485$1498,2000$.

LAHOUTI, M.; PETERSON, P.J. Chromium accumulation and distribution in crop plants. Journal of the Science of Food and Agriculture, v.30, p.136-142, 1979.

LARCHER, W. Ecofisiologia vegetal. Trad. de C.H.B.A. Prado. São Carlos: Rima, 2000. 531p. 
LUZ, C. Mercado de couro curte crescimento tanto interno quanto externo. Latin Chemical, v.9, p.35-37, 2003.

MALAVOLTA, E.; VITTI, G.C.; OLIVEIRA, S.A. Avaliação do estado nutricional das plantas: princípios e aplicações. 2.ed. Piracicaba: Potafos, 1997. 319p.

MASCARENHAS, H.A.A.; FALIVENE, S.M.P.; HIROCE, R.; MANFREDINI, S.; ANGELOCCI, L.R. Efeitos da salinidade do solo sobre dois cultivares de soja. Revista Brasileira de Ciência do Solo, v.5, p.105-109, 1981.

MATTIAZZO, M.E.; BARRETO, M.C.V.; RODELLA, A.A. Organic matter kinetics mineralization in soils amended with four diffrent organic wastes (compact disc). In: CONGRESS MONDIAL DE SCIENCE DU SOL, 16., Montpellier, 1998. Actes. Montpellier: ISSS, 1998.

MENGEL, K. Turnover of organic nitrogen in soils and its availability to crops. Plant and Soil, v.181, p.83-93, 1996.

MEURER, E.J.; BISSANI, C.A.; SELBACH, P.A. Poluentes do solo e do ambiente. In: MEURER, E. J. (Ed.). Fundamentos de química do solo. Porto Alegre: Genesis, 2000. cap.8, p.151-167.

MILACIC, R.; STUPAR, J. Fractionation and oxidation of chromium in tannery wasteand sewage sludje-amended soils. Environmental Science and Technology, v.29, n.2, p.506-514, 1995.

MK QUÍMICA DO BRASIL. Catálogo de produtos 2004/2005. Portão, 2004. 264p.

MOREIRA, F.M.S.; SIQUEIRA, J.O. Microbiologia e bioquímica do solo. Lavras: Universidade Federal de Lavras, 2002. 625p.

PASSIANOTO, C.C.; CASTILHOS, D.D.; CASTILHOS, R.M.V.; LIMA, A.C.R.; LIMA, C.L.R. Atividade e biomassa microbiana no solo com a aplicação de dois diferentes lodos de curtume. Revista Brasileira de Agrociência, v.7, n.2, p.125$130,2001$.

PAULA, M.A.; SIQUEIRA, J.O. A adição de nitrato de amônio e superfosfato triplo e a simbiose Glycine-Bradyrhizobium-Glomus macrocarpum. Revista Brasileira de Ciência do Solo, v.13, p.155-162, 1989. 
PEREIRA, J.C.; NEVES, M.C.P.; DROZDOWICZ, A. Quantificações das populações de bactérias em geral, de bactérias resistentes a antibióticos e de actinomicetos em solos. Seropédica: EMBRAPA Centro Nacional de Pesquisa de Agrobiologia, 1996. 21p. (Documentos, 26)

PIRES, A.M.M.; ANDRADE, C.A.; MATTIAZZO, M.E. Degradação da carga orgânica, condutividade elétrica e pH de um Latossolo tratado com biossólido incorporado ou em superfície (compact disc). In: FERTBIO2002, Rio de Janeiro, 2002. Resumos. Rio de Janeiro: UFRRJ, 2002.

QUAGGIO, J.A.; MASCARENHAS, H.A.A.; BATAGLIA, O.C. Resposta da soja à aplicação de doses crescentes de calcário em latossolo roxo distrófico de cerrado. Revista Brasileira de Ciência do Solo, v.6, p.113-118, 1982.

RAIJ, B.van. Fertilidade do solo e adubação. Piracicaba: Potafos, 1991. 343p.

RAIJ, B.van; ANDRADE, J.C.; CANTARELLA, H.; QUAGGIO, J.A. (Ed.). Análise química para avaliação da fertilidade de solos tropicais. Campinas: Instituto Agronômico, 2001. 285p.

RENGASAMY, P.; OLSSON, K.A. Sodicity and soil structure. Australian Journal of Agricultural Research, v.29, p.935-952, 1991.

RICHARDS, L.A. (Ed). Diagnosis and improvement of saline and alkali soils. Washington: United States Salinity Laboratory Staff, 1954. 160p. (USDA. Agriculture Handbook, 60).

ROSS, D.S.; SJOGREN, R.E.; BARTLETT, R.J. Behavior of chomium in soil: IV. toxicity to microrganisms. Journal of Environmental Quality, v.10, n.2, p.145$148,1981$.

SANTOS, D.S.; ANDRADE, C.A.; MATTIAZZO, M.E. Degradação da fração orgânica de lodos de esgoto após aplicação no solo (compact disc). In: FERTBIO, Rio de Janeiro, 2002. Resumos. Rio de Janeiro: SBCS; SBM; UFFRJ, 2002.

SAS INSTITUTE. SAS/STAT: user's guide version 8.02 (softwere). Cary, 1999.

SCHOLlES, D.; KOLLING, J.; SELBACH, P.A. Resposta da soja ao nitrogênio mineral na presença e na ausência de calcário e de resteva de trigo. Revista Brasileira de Ciência do Solo, v.7, p.305-309, 1983. 
SELBACH, P.A.; TEDESCO, M.J.; GIANELLO, C.; CAVALLET, L.E. Descarte e biodegradação de lodos de curtume no solo. Revista do Couro, v.4, p.51-62, 1991.

SHEWRY, P.R.; PETERSON, P.J. The uptake and transport of chromium by barley seedlings (Hordeum vulgare L.). Journal of Experimental Botany, v.25, p.785797, 1974.

SOMMERS, L.E.; NELSON, D.W.; SILVIERA, D.J. Transformations of carbon, nitrogen, and metals in soils treated with waste materials. Journal of Environmental Quality, v.8, p.287-294, 1979.

STANFORD, G.; SMITH, S.J. Nitrogen mineralization potentials of soils. Soil Science Society of America Proceedings, v.36, p.465-472, 1972.

STENBERG, B. Monitoring soil quality of arable land: microbiological indicators. Acta Agriculturae Scandinavica.Section B, Soil And Plant Science, v.49, p.1-24, 1999.

VANCE, E.D.; BROOKES, P.C. JENKINSON, D.S. Am extraction method for measuring soil microbial biomass C. Soil Biology and Biochemistry, v.19, p.703707, 1987.

VICTORIA,R.L.; PICCOLO, M.C.; VARGAS, A.A.T. O ciclo do nitrogênio. In: CARDOSO, E.J.B.N.; TSAI, S.M.; NEVES, M.C.P. (Ed.). Microbiologia do solo. Campinas: Sociedade Brasileira de Ciência do Solo, 1992. cap.8, p.105-119.

WONG, J.W.C.; LAI, M.; FANG, M.; MA, K.K. Effect of sewage sludge amendment on soil microbial activity and nutrient mineralization. Environment International, v.24, n.8, p.935-943, 1998. 